\title{
State of the Art and Challenges for Offshore Integrated Multi-Trophic Aquaculture (IMTA)
}

\author{
Bela H. Buck ${ }^{1,2,3 *}$, Max F. Troell ${ }^{4,5}$, Gesche Krause ${ }^{1,3}$, Dror L. Angel ${ }^{6}$, Britta Grote ${ }^{1}$ and \\ Thierry Chopin ${ }^{7}$
}

${ }^{1}$ Alfred Wegener Institute Helmholtz Centre for Polar and Marine Research, Bremerhaven, Germany, ${ }^{2}$ Faculty 1, Applied Marine Biology, Bremerhaven University of Applied Sciences, Bremerhaven, Germany, ${ }^{3}$ SeaKult Consulting, Bremerhaven, Germany, ${ }^{4}$ The Beijer Institute, Swedish Royal Academy of Sciences, Stockholm, Sweden, ${ }^{5}$ Stockholm Resilience Centre, Stockholm University, Stockholm, Sweden, ${ }^{6}$ Department of Maritime Civilizations, Charney School of Marine Science, University of Haifa, Haifa, Israel, ${ }^{7}$ Seaweed and Integrated Multi-Trophic Aquaculture Research Laboratory, University of New Brunswick, Saint John, NB, Canada

OPEN ACCESS

Edited by:

Mercedes González-Wangüemert, Centro de Ciências do Mar (CCMAR),

Portugal

Reviewed by:

Libin Zhang,

Institute of Oceanology (CAS), China

Renato A. Quiñones,

University of Concepción, Chile

*Correspondence:

Bela H. Buck

bela.h.buck@awi.de

Specialty section:

This article was submitted to Marine Fisheries, Aquaculture and

Living Resources,

a section of the journal

Frontiers in Marine Science

Received: 28 December 2017

Accepted: 24 April 2018

Published: 15 May 2018

Citation:

Buck BH, Troell MF, Krause G,

Angel DL, Grote $B$ and Chopin T

(2018) State of the Art and Challenges

for Offshore Integrated Multi-Trophic

Aquaculture (IMTA).

Front. Mar. Sci. 5:165.

doi: 10.3389/fmars.2018.00165
By moving away from coastal waters and hence reducing pressure on nearshore ecosystems, offshore aquaculture can be seen as a possible step towards the large-scale expansion of marine food production. Integrated multi-trophic aquaculture (IMTA) in nearshore water bodies has received increasing attention and could therefore play a role in the transfer of aquaculture operations to offshore areas. IMTA holds scope for multi-use of offshore areas and can bring environmental benefits from making use of waste products and transforming these into valuable co-products. Furthermore, they may act as alternative marine production systems and provide scope for alternative income options for coastal communities, e.g., by acting as nodes for farm operation and maintenance requirements. This paper summarizes the current state of knowledge on the implications of the exposed nature of offshore and open ocean sites on the biological, technological and socio-economic performance of IMTA. Of particular interest is improving knowledge about resource flows between integrated species in hydrodynamic challenging conditions that characterize offshore waters.

Keywords: offshore aquaculture, extractive species, open ocean aquaculture, multi-use, sustainable aquaculture, IMTA, socio-economic factors

\section{INTRODUCTION}

The increasing world population has a growing appetite for seafood and, with stagnating supply from capture fisheries, there is a pressure on aquaculture to fill this gap. The transition from fisheries to aquaculture has been growing at an average rate of $>6 \%$ annually; over the past decade and today, aquaculture supplies over half of the fish consumed globally (FAO, 2016). In 2013 , combined global production of farmed fish and shellfish reached $78.5 \%$ of capture fisheries production (FAO, 2014, 2016). In 2014, farmed seaweed production reached 27.3 million metric tonnes (wet weight), worth US $\$ 5.6$ billion and represented the largest group of maricultured organisms (FAO, 2016). Farmed seaweed production now represents $95.6 \%$ of the global seaweed supply (Chopin, 2018a). Aquaculture is increasingly expanding in coastal waters, including landand sea-based cultures in both marine and brackish water environments. In addition to increasing conflicts with various inshore and nearshore stakeholder groups (Buck et al., 2004), aquaculture may have deleterious effects on coastal ecosystems, potentially jeopardizing further expansion of 
coastal aquaculture (Naylor et al., 2000; Naylor and Burke, 2005; Buchholz et al., 2012; Froehlich et al., 2017a).

Studies have indicated that negative environmental impacts from offshore fin-fish systems (i.e., nutrient release) can be reduced or minimized by proper siting and sound farm operation (best management practices) (Ryan, 2004; Alston et al., 2005; Langan, 2007; Aquaculture Planning and Advocacy, 2009; Kona Blue Water Farms, 2009). However, other studies suggest that released nutrients from offshore fish-cages may be transported in a concentrated (non-dispersed) manner to locations far from the point of release (fish-farm) (Løland, 1993; Venayagamoorthy et al., 2011). Thus, farm waste management, by means of water mixing and dispersal, may be sufficient for single small scale systems but not for larger or aggregated farm units.

In addition, although the onset of microalgae blooms in open waters mainly are controlled by large scale climate and nutrient patterns, large volumes of dissolved nutrients could have an impact on phytoplankton composition and the potential to trigger the onset of algae blooms (including toxic species Folke et al., 1994; Glibert and Burford, 2017).

Situating aquaculture even further offshore may reduce environmental impacts and stakeholder conflicts, which recur in coastal systems, and allow expansion of the operations to enable large-scale growth in this sector (Corbin, 2007; Troell et al., 2009; Gentry et al., 2017). Suitable sea area is currently not a limiting factor for expanding farming offshore, but is more related to economics and finding sustainable feeds, and large-scale system designs.

Future changes in water temperature and water chemistry due to climate change could, however, lead to reduction of suitable ocean farming areas (Troell et al., 2017; Oyinlola et al., 2018).

Integrated multi-trophic aquaculture (IMTA) is the cocultivation of fed species (such as finfish or shrimp) together with extractive species, such as suspension-feeding (e.g., mussels and oysters) and deposit-feeding (e.g., sea-cucumbers and seaurchins) invertebrates and macroalgae (e.g., kelps), which may feed on the organic and inorganic effluents generated by the fed species. By establishing such integrated cultivation systems, the sustainability of aquaculture may be increased (Chopin et al., 2001; Neori et al., 2004; FAO, 2006; Buchholz et al., 2012). However, in order for IMTA to be economically viable, each of the individual components must be marketable (Chopin et al., 2008), or adding value through accounting for the ecosystem services that extractive species provide (Buchholz et al., 2012).

The aim of this paper is to identify the various challenges for adopting IMTA in offshore environments and to propose ways to overcome these constraints.

\section{DEVELOPMENT OF THE OFFSHORE IMTA CONCEPT}

\section{From the Early Stages of Offshore Aquaculture}

Offshore aquaculture has been described in many ways (e.g., HR, 2011; Buck and Langan, 2017) and until today there is no common understanding of the term "Offshore." Although the term "offshore" suggests a given distance from the shoreline, this does not apply in many cases, especially when exposed conditions may be found within 1-2 km from shore. Therefore, a more precise definition of offshore aquaculture, which is oriented toward zoning, as defined in the United Nations Convention on the Law of the Sea (UNCLOS), may be more suitable for development of a common legal framework. Aquaculture that is carried out in territorial waters may be legally described as "coastal aquaculture." In contrast, aquaculture that occurs in the Exclusive Economic Zone (EEZ), far beyond a nation's territorial waters, should legally be considered as "EEZ aquaculture" (Rosenthal et al., 2012a,b). However, this clearly complicates the definition of offshore aquaculture even further (Ryan, 2004). Nowadays, the definition most accepted among scientists in this field pertains to the move toward a higher energy environment (Ryan, 2004; Troell et al., 2009; Buck and Langan, 2017), even if this term has no legally binding definition. For the purpose of this paper, we define the term "offshore aquaculture" as (1) the transfer of farm installations from a sheltered environment to a more exposed location as well as (2) the establishment of new aquaculture enterprises in exposed sites, as defined by Ryan (2004); Kapetsky et al. (2013); Lovatelli et al. (2013), and others.

The growing interest to move large scale aquaculture operations further out into the open ocean has made offshore aquaculture an innovative research field, requiring creative solutions to address the challenges of the harsh and/or exposed environment (Polk, 1996; Hesley, 1997; Stickney, 1999; Bridger and Costa-Pierce, 2003; Ferreira et al., 2009; Troell et al., 2009; Chopin et al., 2013; Jansen et al., 2016; Buck and Langan, 2017). Fish cages for summer flounder (Paralichthys dentatus) and haddock (Melanogrammus aeglefinus), as well as blue mussel (Mytilus edulis) longlines, resistant to exposed offshore conditions, were deployed in the mid 90's (Langan, 2001; Langan and Horton, 2003) (Figure 1A). Two pilot projects run by the University of New Hampshire (UNH) and Woods Hole Oceanographic Institute (WHOI) demonstrated the biological and engineering feasibilities of intensive offshore aquaculture using species of different trophic levels. In Norway, studies undertaken at various sites illustrated the concept of transferring aquaculture offshore (Myrseth, 2017). In New Zealand, the government decision to not renew the lease for further inshore mussel farming in Marlborough Sound resulted in the development of technologies to translocate green-lip mussel farms to offshore areas (Simpson, 2015). Initially, most of the accepted seaweed farming protocols were not suitable for exposed, offshore conditions when first attempts were conducted in high energy environments (North, 1987) and thus needed to be drastically modified for offshore sites (especially drag and lift forces; Buck and Buchholz, 2005). Only recently, Buck and Grote (2018) published the first protocol for transferring Laminarian cultivation offshore as a single or multiple species unit, as well as to co-use with offshore wind farms.

Thus, the paucity of scientific studies on the technology, biology, and socio-economic feasibility of offshore aquaculture made these early projects very challenging. The early studies addressed e.g., the quest for techniques that cause less stress on the materials used, which involved solutions such as "one- 
and multiple-point mooring" systems and submersible designs (reviewed in Lovatelli et al., 2013). This situation has not changed during the past 10-15 years, as the number of offshore aquaculture farms worldwide remains low. Today, offshore farms
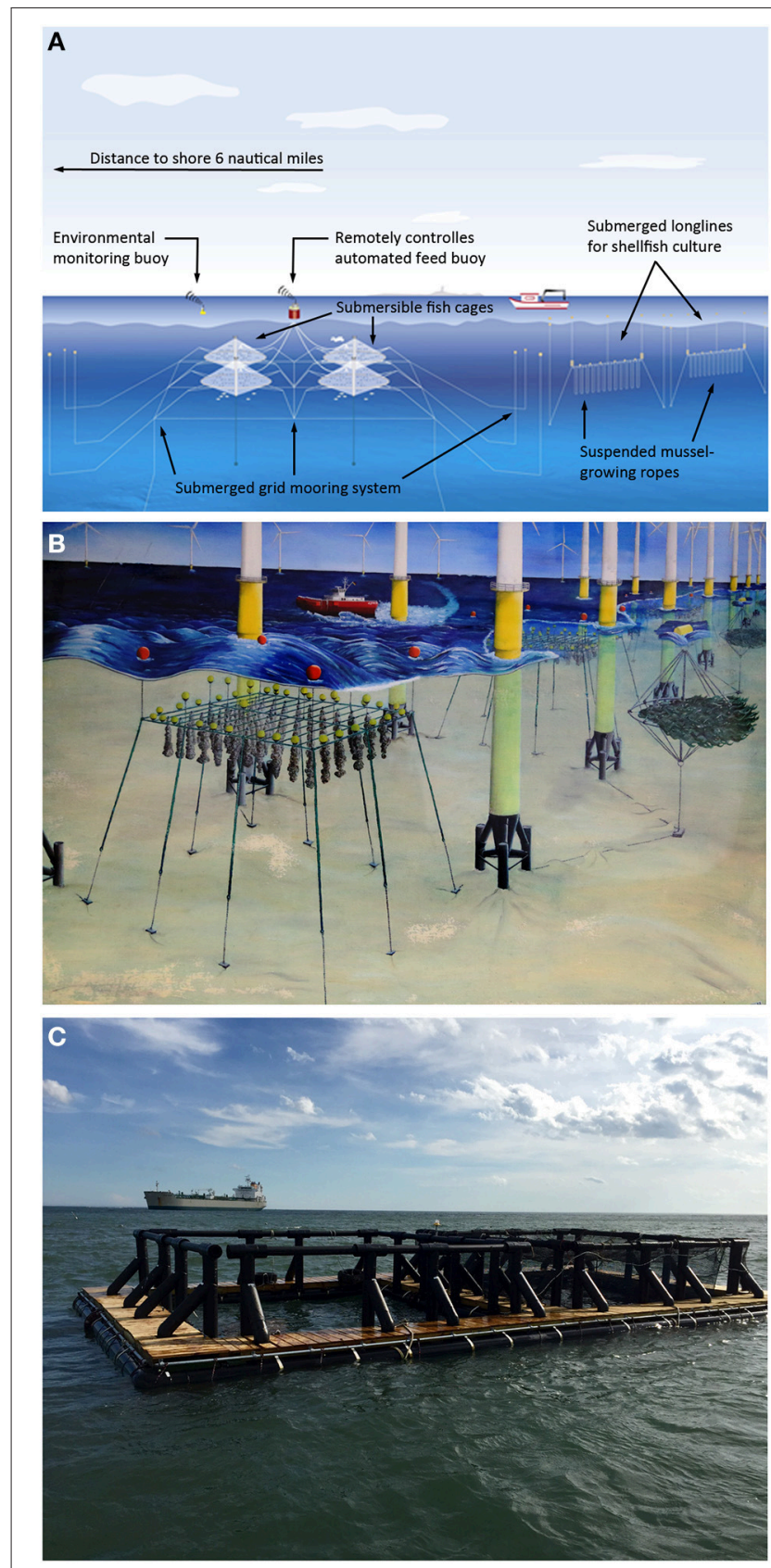

FIGURE 1 | (A-C) IMTA-trials in offshore environments. (A) Diagram of the University of New Hampshire (UNH) offshore installation depicting submerged fish cages and submerged shellfish longlines (top); (B) Extractive aquaculture in a German wind farm with seaweeds and mussels (center); (C) First pilot-scale set-up of an open ocean, integrated multi-trophic aquaculture raft with steelhead trout, blue mussels and sugar kelp deployed off the coast of New Hampshire by UNH (bottom). [Images $(\mathbf{A}, \mathbf{C})$ with permission of the publisher modified after (Buck et al., 2017b), (B) with permission of the publisher modified after (Buck and Langan, 2017)]. grow yellowtail (Seriola rivoliana) in the open ocean off Kona, Hawaii, and off Bahia de La Paz, Mexico, as well as gilthead seabream (Sparus aurata) off the coast of Ashdod (Israel) in the Mediterranean Sea. Numerous long-term experiments on mussel and oyster culture systems have been conducted in exposed hydrodynamic conditions in the open ocean (Table 1). However, since the first trials at UNH in the 90's, there have been very few studies on offshore IMTA. Research projects, starting in 2001, integrated offshore extractive species culture in combination with fish into offshore wind farm areas in the German Bight (Buck and Langan, 2017; Buck et al., 2017a,b) (Figure 1B). These multiuse projects are of prime interest nowadays in some developed countries as marine space is limited.

Supported by NOAA Saltonstall-Kennedy Grant Program and New Hampshire Sea Grant scientists from the University of New Hampshire (UNH), local manufacturers and fishermen together developed a new IMTA raft for integrated marine fish (steelhead trout-Oncorhynchus mykiss irideus, 2 tons/year),

TABLE 1 | Long-term experiments with extractive species (mussel, oyster, seaweed) culture systems conducted in harsh hydrodynamic conditions in the open ocean.

\begin{tabular}{|c|c|c|}
\hline Country & Species & References \\
\hline Germany & $\begin{array}{l}\text { Mussel (Mytilus edulis) } \\
\text { Oyster (Crassostrea gigas, } \\
\text { Ostrea edulis) }\end{array}$ & $\begin{array}{l}\text { Buck, } 2007 \\
\text { Brenner and Buck, } 2010 \\
\text { Brenner et al., 2012 } \\
\text { Pogoda et al., 2011, 2012, } \\
2013 \\
\text { Buck et al., 2017a,b }\end{array}$ \\
\hline USA & Mussel (Mytilus edulis) & Langan and Horton, 2003 \\
\hline Belgium & Mussel (Mytilus edulis) & Delbare, 2001 \\
\hline France & $\begin{array}{l}\text { Mussel (Mytilus galloprovincialis) } \\
\text { Oyster (Crassostrea gigas, } \\
\text { Ostrea edulis) }\end{array}$ & Danioux et al., 2000 \\
\hline
\end{tabular}

\begin{tabular}{lll}
\hline Germany & $\begin{array}{l}\text { Brown seaweed (Laminaria } \\
\text { digitata, Saccharina latissima) }\end{array}$ & $\begin{array}{l}\text { Lüning and Buchholz, 1996 } \\
\text { Buck and Buchholz, 2004, } \\
2005\end{array}$ \\
\hline USA & $\begin{array}{l}\text { Brown seaweed (Macrocystis } \\
\text { pyrifera) }\end{array}$ & $\begin{array}{l}\text { Neushul and Harger, 1985 } \\
\text { Neushul et al., 1992 }\end{array}$ \\
\hline Norway & $\begin{array}{l}\text { Brown seaweed (Laminaria } \\
\text { hyperborea) }\end{array}$ & $\begin{array}{l}\text { Bakken, 2013 } \\
\text { SES, 2015a,b }\end{array}$ \\
\hline
\end{tabular}

The Netherlands Brown seaweed (Laminaria Hortimare, 2016 digitata, Saccharina latissima)

\begin{tabular}{lll}
\hline France & Brown seaweed (Saccharina & Lasserre and Delgenès, \\
& latissima) & 2012 \\
& Langlois et al., 2012 \\
& Marfaing, 2014
\end{tabular}

\begin{tabular}{lll}
\hline UK & Brown seaweed & KFM, 2014 \\
\hline Israel & $\begin{array}{l}\text { Green and red seaweed (Ulva } \\
\text { rigida, Gracilaria bursa-pastoris) }\end{array}$ & Korzen et al., 2016 \\
&
\end{tabular}


shellfish (blue mussels-M. edulis, 6 tons/year) and seaweed (sugar kelp-Saccharina latissima, one ton/year) production (Figure 1C, Chambers, 2013). This raft was deployed in August 2015 and was designed to provide a four-season source of aquaculture products while also increasing revenue for struggling fishermen as well as removing excess nitrogen from the water body (Zeiber, 2015; Swift, 2016; Buck et al., 2017a).

Whereas the data presented in these studies include a variety of systems and species, most trials consisted of single species (monoculture) systems, i.e., not all were planned and conducted with a full IMTA design in mind. This implies that IMTA experiments are still needed to derive knowledge about suitable methodologies and the environmental and socioeconomic viability of offshore IMTA operations. This will require input from various scientific disciplines, as is the norm in the development of innovative aquaculture systems (Turner, 2001; Bridger and Costa-Pierce, 2003; Pérez et al., 2003; Dalton, 2004; Naylor and Burke, 2005; Chopin, 2011; Hughes and Black, 2016).

\section{Multi-Stakeholder Perspective in Offshore Waters}

Aquaculture is a relatively recent addition to the divergent spatial, economic and political interests and conflicts among the many coastal stakeholders (especially in the western world, Krause et al., 2003), e.g., access to fishing grounds, shipping, marine protected areas, tourism, seabed extraction, wind energy, etc. (Gentry et al., 2017; Oyinlola et al., 2018). In general, the stakeholders that operate offshore contrast significantly to those in nearshore areas (Krause et al., 2011; Krause and Mikkelsen, 2017). This is mainly a result of differences in the types of activities and resource uses in the two areas, which involve different political and economic considerations. In offshore areas, political conflicts exist mainly between powerful institutions and are the domain of powerful and affluent stakeholders that operate on a global scale. Their concerns will be heard and responded to more readily by policy makers than those of stakeholders with limited financial means and lobbies (Krause et al., 2011). This may result in economic conflicts between local and regional/international entrepreneurs (MichlerCieluch and Krause, 2008; Krause et al., 2011). Due to these fundamental differences between these power relationships of stakeholders, offshore IMTA may require a different governance and management approach in contrast to nearshore IMTA systems.

\section{Development of Multi-Use Systems in Offshore Areas-Combining IMTA With Energy Production}

It may be economically advantageous for offshore aquaculture to be designed as multiple-purpose systems (Jansen et al., 2016), especially when it comes to aquaculture planned in an IMTA framework (Figure 1B). This would allow aquaculture to capitalize on the newly planned, as well as existing, offshore infrastructures, which would save investment costs as such infrastructures are very costly to build and deploy. The first example of a designed synergy between offshore oil/gas platforms and aquaculture took place in the Caspian Sea in 1987, but this enterprise failed from an economic standpoint due to its high operating costs (Bugrov, 1992, 1996). Similarly, large wind farms in offshore areas in the North Sea were designed to include extensive shellfish and macroalgal aquaculture (Buck, 2002, 2004), as well as fish cultivation (Buck et al., 2012) (Figure 2). Accordingly, the wind farms fixed pylons, concrete gravity foundations, metal jackets, tripods or tripiles, offer anchoring possibilities for aquaculture (Buck et al., 2006; Buck and Langan, 2017). To reduce the risk of damage and losses due to a potential collision with the foundations commercial shipping traffic is not allowed in the areas in between wind farm turbines including a $500 \mathrm{~m}$ safety zone around the entire wind farm site. However, as only operation and maintenance vessels of the wind farms companies are approaching the restricted area and as these vessels could also operate the aquaculture farms (MichlerCieluch et al., 2009a,b), there will be less traffic in sensitive areas. Combining wind farms and aquaculture would reduce the footprint of these activities, increase the societal acceptability of offshore development, and provide an ideal opportunity for realizing true multi-use systems (Buck et al., 2004; MichlerCieluch, 2008). McVey and Buck (2008) proposed to combine fish, shellfish and seaweed aquaculture integrated with offshore wind farms (Figure 2) to follow the IMTA concept. Fish cages were incorporated in the infrastructure of the wind turbines, and the seaweed and shellfish systems encircled the cages at an appropriate distance, functioning as a "waste-defence-line." The Open Ocean Multi-use Project (OOMU) in the German Bight (Hundt et al., 2011; Buck and Krause, 2012) presented a tentative nutrient budget and production capacity for this type of IMTA farm (with turbot, kelp and blue mussel). The solid foundations of wind turbines facilitated attachment and mooring of cultivation systems, either directly to the foundations or indirectly in the center of four wind turbines (Buck et al., 2006).

The follow-up project Offshore-Site-Selection (OSS) examined the feasibility of multi-functional use of an offshore site within the German EEZ, combining both wind energy and aquaculture (Grote et al., 2013b). In this project, the nutrient uptake by extractive species was compared to the nutrient discharge from various fed species (seabass, turbot) in a series of small scale experiments (Grote, 2016) and in an experimental-scale recirculation set-up (Grote et al., 2013b). The resulting data were used to calculate the biomass of extractive species required in these IMTA-systems to enable a "0-discharge" approach for offshore use (Grote et al., 2013a). In addition, a variety of spatial co-use scenarios coupling offshore IMTA and wind farms were evaluated in order to design efficient and sustainable marine spatial management strategies (Figures 3A-D). Geographic Information System (GIS) and Multi-Criteria Evaluation (MCE) techniques were employed to determine suitable co-sites in the German EEZ by means of oceanographic and geological/topographic data (temperature, salinity, oxygen, depth, seabed, etc.) for combined seaweed ( $S$. latissima, Laminaria digitata, Palmaria palmata), bivalve (M. edulis, Ostrea edulis, Crassostrea gigas), and fish 


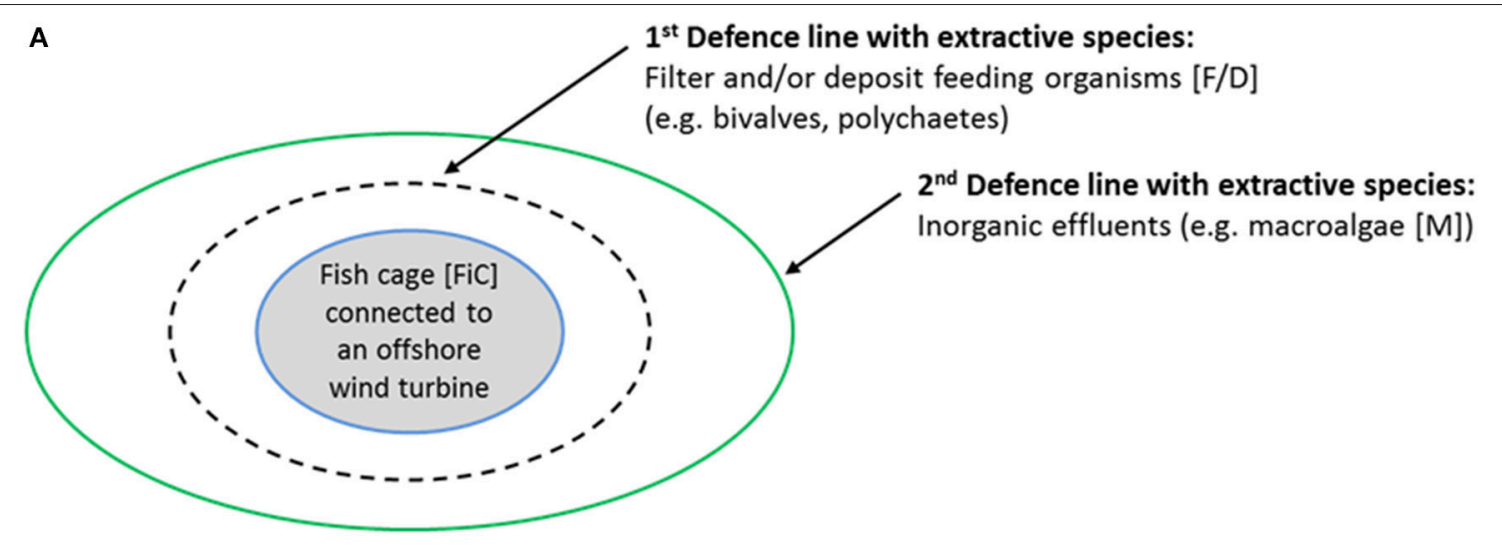

B

C

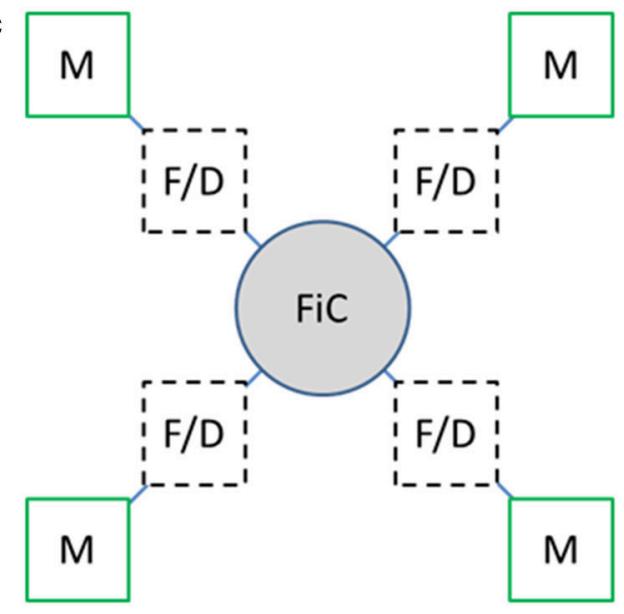

FIGURE 2 | (A-C) Multi-use aquaculture following the IMTA-concept. (A) shows the integration of a central fish cage (FiC) connected to the wind farm foundation with two subsequent "defense lines" including filter/deposit feeding organisms ([F/D] inner circle/black dotted line) and seaweed ([M] outer circle/green line) (McVey and Buck, 2008) (upper image); (B,C) display different setting options for the combination of a central fish farm (FiC) and the surrounding filter/deposit feeding (F/D) and seaweed (M) farms while at the same time allowing O\&M vessels to navigate through the area with direct access to the windmill foundation (bottom left and right).

(Dicentrarchus labrax, Gadus morhua, Scophthalmus maximus, M. aeglefinus) cultivation resulting in high suitability scores for IMTA systems combining some of the studied fish, bivalve and seaweed species (Gimpel et al., 2015). These case studies illustrated the potential to balance between competing needs when considering the combination of offshore wind energy and IMTA in the German EEZ of the North Sea. Moreover, these scenarios may be used by stakeholders and policy/decisionmakers in their search for optimal offshore multiple use and IMTA sites.

Another approach in moving IMTA off the coast into offshore wind farm sites took place at a site off the coast of southerneast South-Korea in 2016 following the South-West Offshore Wind Farm Development Plan (KEPCO and KIOST, 2016) (Figures 4A-E). The objective of this project is, on one hand, the development of technologies for co-locating fisheries and aquaculture with offshore wind farms, and, on the other hand, the improvement of the societal acceptance of offshore wind farms and/or aquaculture by this multi-use concept (Buck et al., 2017b). First trials started in 2016 with IMTA combining fish, sea cucumber, oyster, and seaweed culture.
Overall, the feasibility of a combined fish, shellfish and/or seaweed aquaculture enterprise within offshore wind farming areas depends on such factors as: (1) technological implementation, (2) biological feasibility, (3) environmental sustainability of the enterprise, and (4) the economic feasibility of the operation (Buck et al., 2008a; Buck and Krause, 2012). In the following sections, these factors are discussed in more detail and specifically how they relate to offshore IMTA systems (including systems not associated with energy producing infrastructure).

\section{IMTA IN OFFSHORE ENVIRONMENTS-POSSIBILITIES AND CONSTRAINTS}

Apart from one single site described below, there are no commercial scale IMTA systems in the open ocean under real offshore conditions presently in operation. The only example with large production can be seen in China, where Zhangzidao Fishery Group Co. Ltd. (ZFG) operates a farm of 40,000 ha in size. In 2005, ZFG produced $\sim 28,000 \mathrm{t}$ (US\$ 60 million) following 

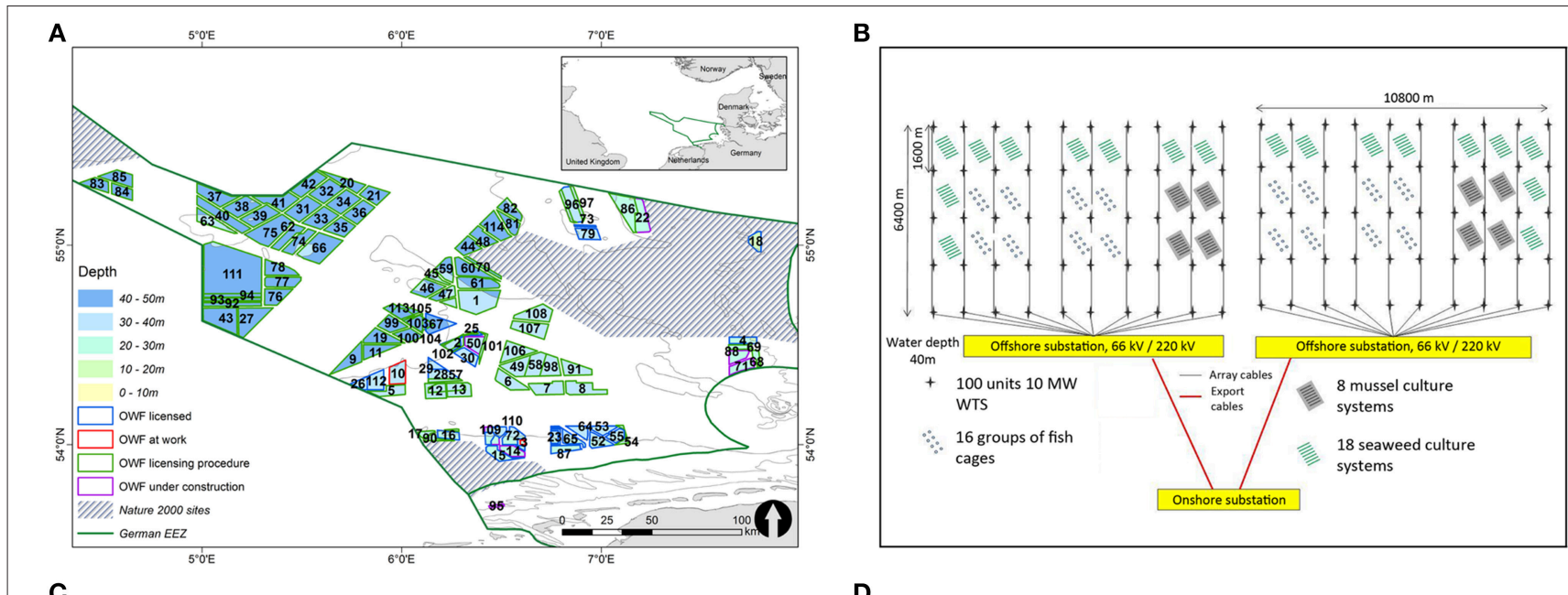

C S.0 E

D

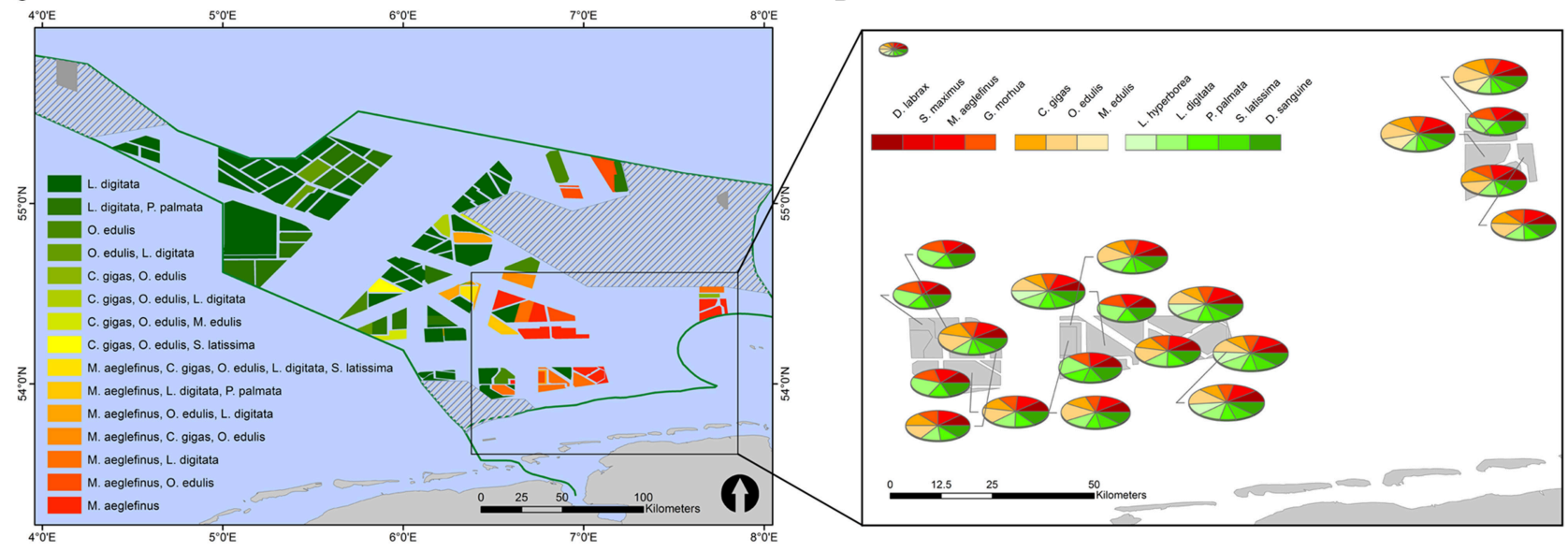

FIGURE 3 | (A-D) Offshore multi-use set-ups with wind farms and IMTA. (A) shows a map of all German offshore wind farms within the EEZ of the German Bight, numbered, colored per depth level and framed per status. Shaded districts show the Nature 2000 areas (upper left). (B) SINTEF-Statoil IMTA design for the North Sea (upper right); (C) displays a map of suitable co-location sites in the German EEZ of the North Sea, colored per aquaculture candidate featuring the highest suitability per wind farm area (lower left) with the enlargement (D) closer to the German coast (North Sea). Results presented depict the conditions given at 10-20 $\mathrm{m}$ depth during spring time (lower right). The size of the pies reflects the height of the relative suitability scores [Images (A,C,D) with permission of the publisher modified after (Stelzenmüller et al., 2017); (B) with permission of the publisher modified after (Buck et al., 2017b; He et al., 2015)].

an IMTA-like multi-species sea-ranching approach including scallops, sea urchins, abalone, and sea cucumbers (Troell et al., 2009; Buck et al., 2017b). The site, located around Zhangzidao Island in the Yellow Sea, is $8 \mathrm{~km}$ offshore, up to $40 \mathrm{~m}$ in depth and characterized by strong currents $\left(\max .100 \mathrm{~cm} \cdot \mathrm{s}^{-1}\right.$ ). We are aware of other large scale IMTA operations in China; they are, however, often in relatively sheltered conditions or inshore water bodies. All other current offshore IMTA-enterprises operate on experimental scale to test biological, technical, and other operational aspects.

Relevant information for designing offshore IMTA with respect to functions and performance can be obtained from offshore single species systems in combination with information from nearshore coastal IMTA systems. However, the technology and system design has to be adapted to the conditions in high energy environments and it has to withstand strong forces induced by high waves and strong currents. As described earlier, there have also been advances for developing IMTA systems in combination with other offshore activities (e.g., oil and wind platforms, see further details below). Several open ocean IMTA demonstration facilities exist in different parts of the world, which may be used as prototypes for future development (Langan, 2004; Partridge et al., 2006; Buchholz et al., 2012). These systems do not encompass all environments and species, and more work is needed to explore additional scenarios. Moreover, it is anticipated that with the emergence of commercial scale offshore systems, there will be options for cost sharing arrangements to reduce the expensive nature of offshore research, and to test the feasibility of IMTA in offshore environments from both a bio-technical and economic point of view.

\section{Biological Feasibility}

As stated earlier, current knowledge on nearshore IMTA systems may be instrumental for guiding IMTA development in offshore environments. However, it is essential to clearly 

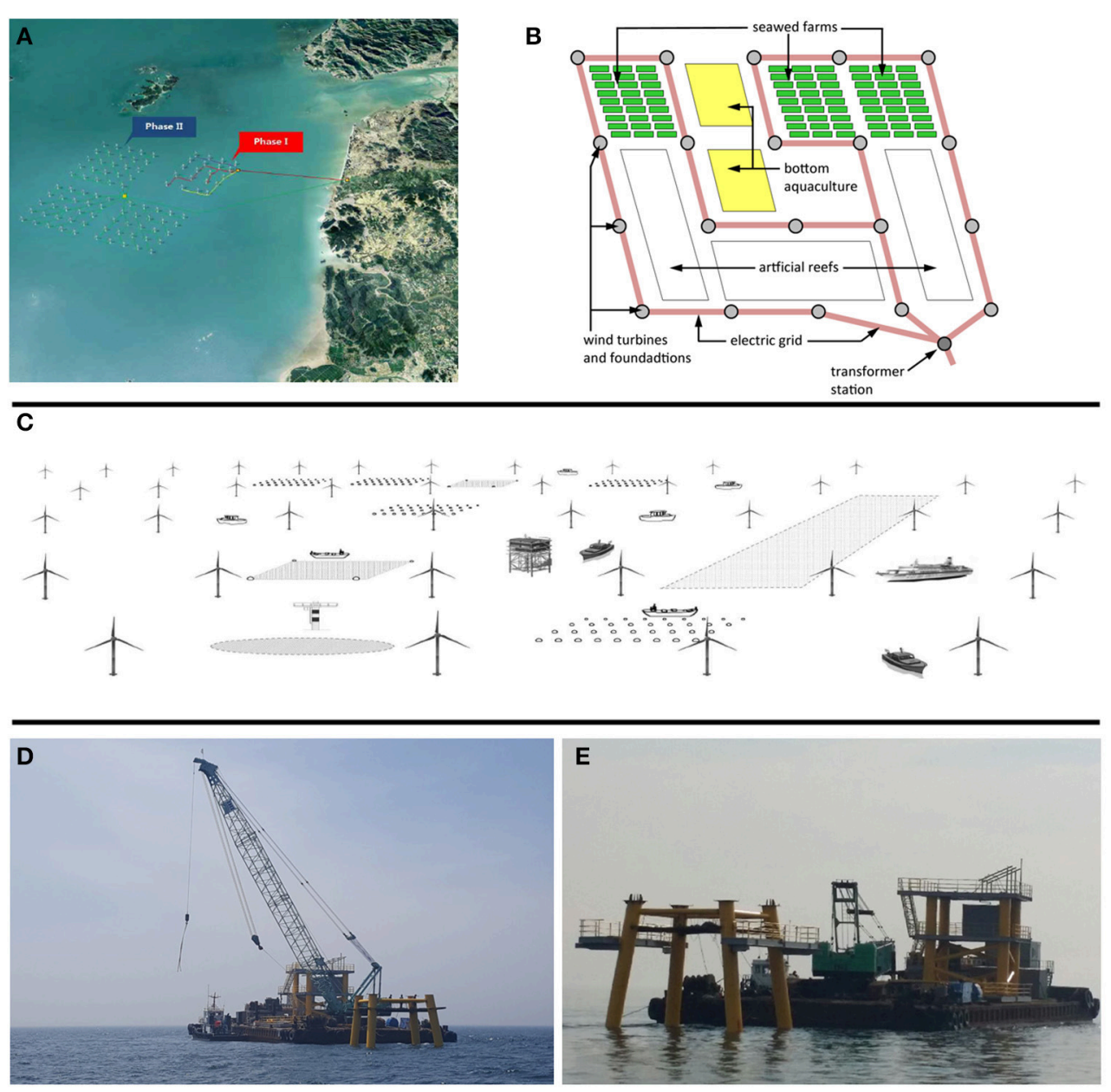

FIGURE 4 | (A-E) IMTA concepts as a co-use in offshore wind farms. (A) Aquaculture co-location site within a planned wind farm off the coast of southern-east South-Korea (upper left); (B,C) drawings of the multi-use concepts at the wind farm site as an internal aquaculture layout (upper right) and shown in a profile view, including fish, seaweed and oyster cultivation (centered); (D,E) Deployment of the foundation of an offshore wind turbine within the co-location site of a wind farm, using attachment device for multi-uses (lower left and right) [Images (A-E) with permission of the publisher modified after (Buck et al., 2017b)].

identify the differences and similarities among these contrasting environments. Environmental conditions in offshore and exposed sites will not be suitable for all candidate IMTA species and it is essential to define the ranges of key variables such as water temperature, salinity, nutrients, currents, etc. in advance. One of the most important challenges facing IMTA in offshore environments is whether the candidate species, both extractive and fed, and the infrastructures to cultivate them, can withstand the range of prevailing hydrodynamic forces. The acceleration caused by breaking waves and swell may cause considerable stress to the cultured organisms (Carrington et al., 2001; Buck and Buchholz, 2005; Buck et al., 2008b; Gaylord et al., 2008; Troell et al., 2009), which could render them unfit for offshore IMTA.

Considerable effort has already been invested in the testing of cage structures for fish as offshore monoculture fish farms venture into exposed environments (Polk, 1996; Hesley, 1997; Stickney, 1999; Bridger and Costa-Pierce, 2003). It is advisable to seek fish species with high market value for offshore farming due to the increased costs of offshore operations (see section Discussion later in the text), which usually involves carnivorous species (Naylor and Burke, 2005; Hundt et al., 2011). Significant husbandry knowledge already exists for many of these species; however, additional information related to suitable stocking densities, feeding behavior, etc. specifically for offshore conditions may be needed.

From our understanding, the environmental impacts of offshore fish farming have been reduced and the feeding improved, but the release of dissolved and particulate material has still not be studied, as this will differ between nearshore fish-cage farming and offshore farming (Lin and Bailey-Brock, 2008; Reid et al., 2009). We are fully aware that "Dilution is not the solution to pollution" and point out that further research is needed to get more insight in the impacts, as well as to improve management, feeding regime, waste output and uptake by associated other species. 
Table 2 displays variables that play an important role when considering transferring IMTA installations from the nearshore to the open ocean.

In comparison to fish swimming in cages, bivalves and macrophytes are generally attached to substrates, by means of byssus (mussels) or holdfasts (seaweeds). It has been shown that large kelps, such as S. latissima and L. digitata, are probably suitable for offshore farming, when transferred at sea at an early life stage, as the fastening as well as the lamina (blade) adapt to strong hydrodynamic forces. In addition seaweed blades also develop a more streamlined morphology in high energy conditions, which reduces drag and lift forces, and holdfasts develop a better attachment (Buck and Buchholz, 2005). These adaptations can be enhanced by exposing post-settlement spores to turbulent conditions (by means of pumps) in hatcheries.

Nutrient manipulations in seaweed cultures (concentrations, nitrogen/phosphorus ratios, and nutrient application regimes) revealed its effect on biomass yield and productivity, as well as on epiphytic production (Friedlander et al., 1991). For example, in Gracilaria conferta culture, the high nutrient concentrations

TABLE 2 | Variables to be considered when installing an IMTA system and the benefits/limitations of offshore installations.

\begin{tabular}{|c|c|c|}
\hline Variable & Description & Offshore advantages/limitations \\
\hline Nutrients & $\begin{array}{l}\text { - A minimal concentration of nutrients (e.g., nitrates, ammonia, } \\
\text { phosphates) is needed for the respective seaweed candidates to have } \\
\text { good growth rates. Prevailing nutrient concentrations and corresponding } \\
\text { growth rates are species-specific. } \\
\text { - Nutrient concentrations correspond to the concentrations of } \\
\text { phytoplankton which influences the growth rates of bivalves during } \\
\text { filter-feeding. }\end{array}$ & $\begin{array}{l}\text { - In most cases nutrient concentration would decrease } \\
\text { further offshore. However, in some offshore areas nutrient } \\
\text { concentrations are still high (e.g., North Sea }{ }^{a} \text { ). } \\
\text { - In all offshore areas proper site-selection is needed. } \\
\text { - Could lead in some coastal areas to eutrophication originating } \\
\text { from urban sewage/agricultural operations which in turn could } \\
\text { harm the growth of mussels. }\end{array}$ \\
\hline
\end{tabular}
with distance from shore.

\begin{tabular}{ll} 
Light & Appropriate light penetration is needed for seaweed species. \\
\hline Fouling & - As fouling is one of the factors that increase cost of cultivation, timing of \\
& deployment may reduce fouling. \\
\hline Position of IMTA & - Influence on nutrient uptake. \\
components & Seaweed blade entanglement, which could lead to biomass loss and to \\
- & Mussels/oysters could be detached from their substrates. \\
- Fish could have problems with strong currents and wave action. & Culture system could influence water flow, flushing of wastes, and \\
& oxygen concentration.
\end{tabular}

- Usually better for seaweeds, which can be cultivated at greater depth (submerged cultivation mode) due to increased clarity of offshore waters, to avoid mechanical stress at the surface ${ }^{\mathrm{b}}$.

- Usually fouling of cages, longlines, buoys, etc. at offshore locations is less, being away from nearshore larval sources.

- Due to light and current conditions, positioning of components could be over greater distances and depths, which could be beneficial for navigation by maintenance/harvesting boats.

- Positions could be combined in a multi-use manner with already existing offshore platforms (e.g., wind turbines) ${ }^{\mathrm{C}}$.

- Submerged design would become necessary to avoid mechanical stress on technical components and candidate species.

- Only current resistant species can be used or site selection should exclude areas with extreme currents/high waves.

\begin{tabular}{ll}
\hline Current strength & - Influences morphology of extractive species. \\
& - Influences nutrient and food supply and delivery. \\
& - Influences dispersal of waste and chemicals used
\end{tabular}

- Can be beneficial for flushing of wastes and nutrients as currents in offshore areas are usually stronger which increases dilution of wastes and chemicals and therefore reducing their bio-availability.

- For shellfish, growth increases with stronger currents until threshold ${ }^{d}$.

- Exposure to high waves/swell may reduce production rates due to the loss of shellfish through detachment ${ }^{e}$ or mortality due to shell abrasion ${ }^{f}$.

\begin{tabular}{ll}
\hline Wave dynamics $\quad$ Influences mechanical stress on extractive species as well as mooring \\
and anchoring system.
\end{tabular}

Disease/parasites - Integration of filter feeders can reduce diseases and parasite infestationg.
- Due to better light penetration, extractive species can be deployed deeper thus avoiding strong wave dynamics.

a Buck and Buchholz, 2004.

${ }^{b}$ Buck and Buchholz, 2005.

${ }^{c}$ Buck et al., 2004.

${ }^{d}$ Rosenberg and Loo, 1983; Wildish and Kristmanson, 1988.

escarratt, 1993.

fPogoda et al., 2012.

gSkår and Mortensen, 2007; Molloy et al., 2011; Bartsch et al., 2013.

${ }^{h}$ Buck et al., 2005; Pogoda et al., 2011. 
with low irradiance in summer had a positive effect on its growth rate and reduction of its epiphytes, while in winter time only irradiance effected the growth of the seaweed and epiphytes. Therefore, the knowledge on all potential seaweeds for aquaculture will influence species selection, as well as which seasonal time slot fits best. The last consideration is very important: taking irradiance and temperature into account, the growth rates of S. latissima and P. palmata could not $100 \%$ correspond with the increase of nutrient releases from the growing fish in the cages (Grote et al., 2013b).

The effective control of epiphytes in tank cultures has used freshwater additions, oxygen (air exposure), chemicals and other practices (Buschmann et al., 1994; Fletcher, 1995). In nearshore operations, Porphyra epiphytes have been managed by utilizing the tide that exposes the seaweeds to air, or by means of specially designed emersion/immersion systems (Oohusa, 1993), but such measures are most probably not feasible in offshore systems (Buschmann et al., 1997). Chopin et al. (2004) addressed the epiphyte problem by timing the transfer of seaweeds from the hatchery out to longlines at an integrated salmon aquaculture site when epiphyte fouling on kelp ropes was low. However, by integrating bivalves with e.g., fish cages, the source (e.g., settling mussel larvae) is effectively transferred to these offshore areas and could impact negatively on co-cultured seaweeds. Heavy sets of mussels settling on Gracilaria longlines situated next to salmon cages can result in large losses of seaweed biomass during certain times of the year (Halling et al., 2005). In addition, herbivorous fishes may threaten the cultivated seaweeds as observed by Ganesan et al. (2006). They found that Ulva lactuca grown on lines adjacent to seabream cages in the Gulf of Aqaba, Red Sea, were efficiently cropped and cleaned by young siganids (rabbitfish). In Galicia (Spain), Peteiro and Freire (2012) observed a number of different Sparidae fish species feeding on the macroalgae S. latissima and Undaria pinnatifida. This grazing problem is caused by the cages functioning as attractors for wild fish species (e.g., Dempster et al., 2002; Ozgul and Angel, 2013).

The integrated farming of vastly different organisms with different needs is complex (Zamora et al., 2016). Challenging is also the optimization of how the extractive species get exposed by the waste-products of the fed species (Troell et al., 2003, 2009; Granada et al., 2016). The great variability, both spatially and temporally, in hydrodynamic conditions, pelagic primary productivity, water seston concentrations, farm waste characteristics, etc. among sites will affect the outcome and success of the IMTA system and may limit our ability to generalize the results (Troell and Norberg, 1998; Troell et al., 1999, 2009, 2011; Cheshuk et al., 2003; Navarrete-Mier et al., 2010; Cranford et al., 2013). Theoretically, offshore farms, with higher flushing rates and, therefore, greater flux of farm wastes, should yield greater growth of the extractive species but if these species rely on seston and phytoplankton (i.e., mussels), these are most likely less abundant offshore and this will clearly affect growth rates (Troell and Norberg, 1998; Troell et al., 2011; Cranford et al., 2013). If advective currents are generally well described, convective currents (vertical transports) have been much less studied. They may, however, be extremely important when co-cultured components are at different levels in the water column. There is, thus, a need for further engineering solutions when culturing in such environments and especially for IMTA systems, in which ascending or descending currents could be triggered. Commercial mussel farming currently exists in offshore waters in several countries (e.g., Europe: Ireland, Scotland, Germany, the Netherlands, France; North-America: USA; East-Asia: Japan, China; South-Pacific: New Zealand) (Langan, 2012), but these waters are all characterized by having medium to high primary production. There is also a need for further IMTA studies in areas with mesotrophic and oligotrophic conditions, e.g., the eastern Mediterranean (Hughes and Black, 2016).

The scaling of the different species in offshore IMTA systems will have to be calculated for optimization of growth and waste reduction (however it is not possible to optimize for both simultaneously, see Buschmann et al., 2001). From modeling IMTA systems in relatively sheltered conditions in Canada, calculations showed that the mean ratios of the kelp weight, Alaria esculenta, required to completely sequester nutrients excreted per unit weight of salmon, Salmo salar, production were $6.7( \pm 1.5)$ :1 for nitrogen, $4.8( \pm 3.0)$ :1 for phosphorus, and 5.8 $( \pm 1.4): 1$ for carbon. The mean ratios for S. latissima were 12.9 $( \pm 2.7)$ :1 for nitrogen, $10.5( \pm 6.2): 1$ for phosphorus, and 10.2 ( \pm 2.2$): 1$ for carbon (Reid et al., 2013). It is, however, important to note that not all inorganic nutrients from cultured fish would be available to seaweeds within an IMTA concept, nor should 100\% nutrient sequestration need be the only successful endpoint in such systems.

\section{Technology for Offshore IMTA}

From a technology point of view, there is disagreement among experts over the justification for taking aquaculture offshore (McElwee, 1996). Successful offshore aquaculture development relies on realistic and cost-effective technological solutions to address the open ocean conditions, including currents, swell, waves, seafloor depth, and such issues as shipping routes, marine mammal migration routes, etc. (North, 1987). Addressing these challenges is generally possible, but the costs may be prohibitive and, therefore, making the operations unsustainable (North, 1987; Posadas and Bridger, 2003; NOAA, 2008; Troell et al., 2009). Experimental-, pilot- and also lately large-scale operations have, however, shown the technical and economic feasibility of offshore fish and mussel farming systems (Langan and Horton, 2003; Olsen et al., 2005; Buck, 2007; Buck et al., 2010; Upton and Buck, 2010). Modern offshore fish farms are similar worldwide. Designs and degrees of automation may vary, but, with the exception of floating closed containment systems (Partridge et al., 2006; Fredriksson et al., 2008), most marine fish cages are operated as flow-through net-pen systems. There are, however, innovative suggestions for closed containment offshore farm systems (Figures 5A-C), such as super-large cages with manned platforms or huge closed containers, included in a ship-design (Myrseth, 2017).

Offshore systems need to be able to withstand continuous waves, currents and storms, and should need minimal maintenance (most routines automated) so that they do not require constant maintenance by personnel. Because there 

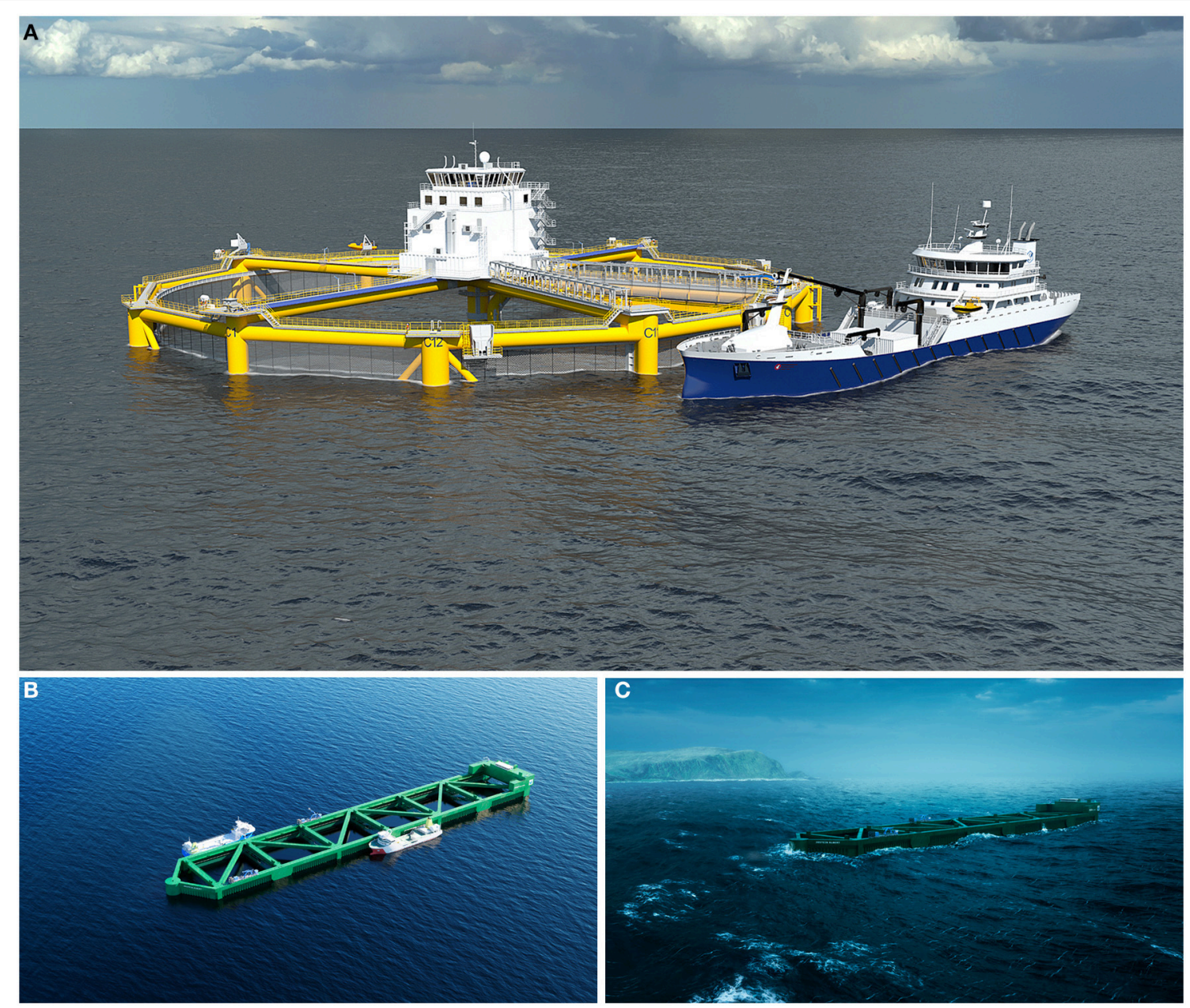

FIGURE 5 | (A) Large offshore fish farm device with a diameter of $110 \mathrm{~m}$, a height of $67 \mathrm{~m}$ and a volume of 245,000 $\mathrm{m}^{3}$ (upper image). This fish farm was just recently built in an Asian shipyard, transferred to Norway and could produce 6,000 t of salmon. (B,C) Havfarm 1: Large aquaculture production unit integrated into a vessel-like floating platform in calm (lower left) and rough (C) conditions at sea (lower right). Havfarm 1 includes next to the large cages a mini-harbour for service vessels, maintenance trolleys along the outer rails providing access to the entire facility, rotatable thrusters to reduce stress on the mooring during storm conditions while also ensuring optimum oxygen supply, and a deep steel louse skirt, which reduces the risk of lice infection as well as protects the facility from being damaged by drifting objects [Image (A) with permission of NSK Ship Design and image (B) with permission of Ocean Farming AS].

are still many uncertainties with respect to site selection and technical design; only a few cost-effective and reliable offshore mooring systems exist. The orbital motion caused by marine forces (Buck and Buchholz, 2004, 2005; Holthuijsen, 2007) may be an especially critical factor that needs to be taken into account in the design of these systems. Culturing techniques generally require that extractive species are contained in nets/socks or entwined, or fastened, to ropes (Buck and Buchholz, 2004; Chopin et al., 2004). The strong hydrodynamic conditions at many offshore sites may preclude farming of species without appropriate attachment methods. For example, following Buck and Buchholz (2004), rope culture of kelps (S. latissima), including longline, ladder and grid constructions, were all unsuitable for exposed conditions. However, a ring design proved successful, because its one-point mooring device allowed for limited movement (rotation and submergence) of the entire system while still providing enough sunlight to support photosynthesis.

Other systems for offshore Laminarian cultivation were tested in the Netherlands and Sweden (Buck et al., 2017b). One of the first trials to farm seaweeds in the North Sea, off the coast of the Netherlands within a wind farm site, was conducted by Ecofys and Hortimare in 2012 (Buck et al., 2017b). The system consisted of a set of steel cables equipped with anchors and floating buoys, tautened $2 \mathrm{~m}$ below the water surface and covering a field of $20 \times$ $20 \mathrm{~m}\left(400 \mathrm{~m}^{2}\right)$. Horizontal nets with seaweed sporophytes were deployed between these cables. As a result of these successful trials, Stichting Noordzeeboerderij (the North Sea Farm) and Hortimare launched in 2015 a small scale offshore farm $10 \mathrm{~km}$ North-East of the Island of Texel.

The Norwegian company Seaweed Energy Solutions AS (SES) patented a structure, called the Seaweed Carrier, to enable mass 
seaweed cultivation on an industrial scale (SES, 2015a). The Seaweed Carrier (Figures 6A,B) has a sheet-like structure that mimics very large seaweed blades, moving freely with the water flow from a single mooring on the seabed. This carrier seeded with sporophytes, said to withstand rough water, consists of only a few moving parts, has low cost and allows for easy harvesting (Buck et al., 2017a).

Ocean Rainforest $\mathrm{Sp} / \mathrm{F}$ designed and tested a system to develop a cultivation method that can be applicable and economically profitable in the western world when cultivating S. latissima and $A$. esculenta (Bak et al., unpublished). The farm design comprises of a longline macroalgal cultivation rig (MACR) for exposed and deep water locations (water depth $>50 \mathrm{~m}$ ) and offshore conditions (Figures 6C-E). The rig consists of a horizontal fix line (backbone) with vertical seed lines hanging perpendicular from the backbone. Main advantages are that it is light, robust, and easy to cultivate and harvest similar to longline mussel aquaculture, and that the main line provides the capability to switch production between species between harvests, thus maximizing utilization year round. The current farm site is north of the village of Funningur and already withstood winds up to $62 \mathrm{~m} / \mathrm{s}$ and wave heights of 7-8 $\mathrm{m}$ without any damage.

Halling et al. (2005) found that Gracilaria cultivated on longlines in heavily exposed waters in Chile lost considerable biomass during growth. This loss was reduced by employing a modification of the rope entwining method (Westermeier et al., 1993).

Another challenge in offshore waters is that substrates for mussel cultivation, such as collector ropes for spat collection as well as for grow-out, may have limited success in such harsh environments. The plaques (attachment area) on the mussel byssus threads can be dislodged if the available attachment surface is too small or filamentous or too long. Therefore, collectors will have to be adapted to avoid loss (Brenner and Buck, 2010). Devices for offshore oyster cultivation are still in their infancy. Lantern nets can be used for oyster farming but are limited in space and do not prevent shell abrasion (Pogoda, 2012). This calls for further efforts in technological innovation in platform design for shellfish cultivation (Stevens et al., 2008).

\section{Environmental Benefits and Limitations}

Dissolved nutrients are a key limiting factor that determines macroalgal growth and production rates (Harrison and Hurd, 2001). Nitrogen is often the nutrient that limits algal production in coastal areas, and, by extension, it affects herbivores that rely on microalgae, such as bivalves. Ammonia, the major form of nitrogen excreted by fish, has been shown to accelerate seaweed growth (e.g., Troell et al., 1997) and, as offshore waters usually have lower nitrogen levels than coastal environments, fish (and bivalve) excretion may be important for stimulating seaweed growth there.

It is noteworthy that if background levels of dissolved nutrients are too low, overall seaweed production will be limited regardless of local nutrient enhancement from fish farms (Troell et al., 2003). The same situation would affect particulate matter availability for bivalves as well (Troell and Norberg, 1998). Hydrodynamics, including current strength and direction will affect the success of IMTA systems, as this influences the distribution of nutrients and organic particles from the point sources. As the distribution of farm effluents could determine the appropriate orientation and location of the extractive species within the IMTA systems, any offshore IMTA enterprise, especially when natural dissolved nutrient concentrations and particle load are limited at the particular site, should be carefully located. Offshore sites, where prevailing horizontal and vertical currents would transport nutrients and particles away from the reach of the extractive species should be avoided. In general, sites with (1) anthropogenic-induced eutrophication through larger river inputs, (2) atmospheric depositions, (3) upwelling, as well as (4) locations presenting natural eutrophication should be sought after. All these influences can increase nutrient concentrations in offshore waters, stimulating growth of bivalves and seaweeds, i.e., independently from fed aquaculture nutrient enrichment (Buck and Buchholz, 2004; Buck, 2007). For example, the offshore test site for mussel and seaweed cultivation at Roter Sand (17 nautical miles off the coast of Bremerhaven) is in the vicinity of the estuaries of the rivers Elbe and Weser and, therefore, influenced by the river-run nutrient load (Buck, 2007). However, it is important to also understand how such environments may affect fed species, as these may not be optimal for fish growth. In some upwelling areas, like the Benguela current or the Humboldt current, hypoxia events occur frequently and this can be detrimental for cultivated species (Ekau et al., 2010; Hernández-Miranda et al., 2010, 2012, 2017).

The availability of dissolved nutrients and particles released from submerged fish cages to seaweeds and bivalves situated nearby will depend on the depth at which the respective structures will be deployed and the direction of the effluent plume. If fish cages are situated at depth (to avoid wave stress and swell), the flux of effluent nutrients/particles reaching surface waters would be reduced, i.e., submerged systems would only support growth of seaweeds and bivalves at the surface if deep water is lifted (either naturally or artificially). Even if some less light-adapted seaweed species could potentially be submerged several meters, as well as bivalves cultured for grow-out only (no spat collection), it will be necessary to model the flux of nutrients and particles in order to design systems that will optimize the delivery of farm effluents to the macroalgal and shellfish IMTA components. Joint ventures between industry with experience in underwater turbine energy and in offshore aquaculture could create interesting synergies by combining technologies, minimizing ecological footprints, and reducing costs by means of multiple-use of the same infrastructure.

The environmental impacts of large or aggregated offshore farms are currently unknown but will probably be less when compared to nearshore farms, based on a comparison of flushing rates and seafloor depth. Offshore aquaculture farms are likely to be much larger than existing, nearshore installations, due to the higher overall costs and these large farms will generate large waste streams per farm. Moreover, valuable deep sea ecosystems (e.g., deep sea corals, sponges, soft sediments, etc.) can be negatively impacted. It is likely that the assimilative capacity of sediments in 

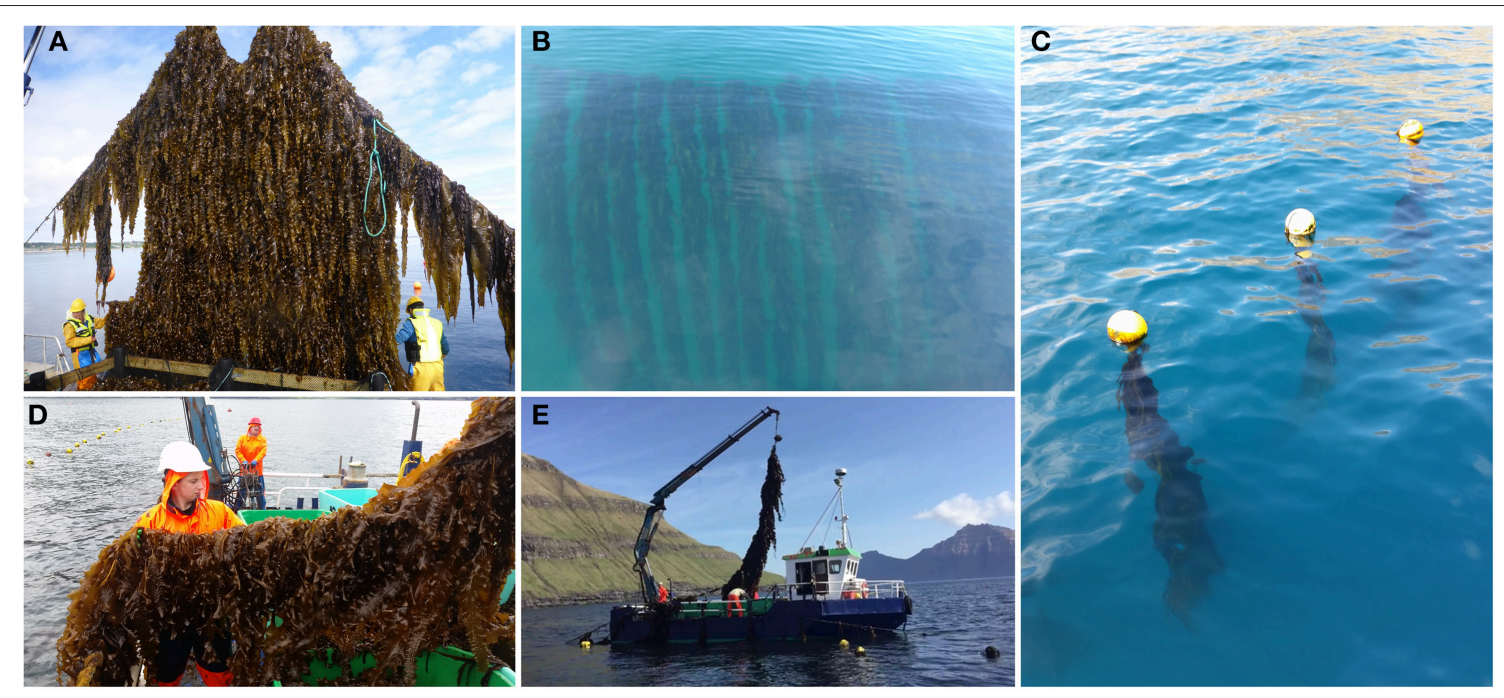

FIGURE 6 | (A-E) Offshore seaweed farms in Norway (Seaweed Carrier) and Faroe Islands (Macroalgal Cultivation Rig-MACR). (A) Harvest of seaweeds growing on the Carrier (upper left); (B) Underwater image of the kelps growing on the Carrier devices (upper centered); (C) Seaweeds hanging perpendicular from the backbone (upper right). (D,E) Harvest of Saccharina latissima on board of the vessel Tongul (lower left and centered) [Images (A,B) with permission of SES, Norway, and the publisher modified after (Buck et al., 2017b); (C-E) with permission of Ocean Rainforest Sp/F, Faroe Islands].

deeper waters can be reduced and dissolved nutrients may also reach coastal areas in more concentrated forms than could be expected from the anticipated dilution effect (Venayagamoorthy et al., 2011).

To achieve a significant nutrient reduction by seaweeds, the latter will have to encompass large areas (Troell et al., 1997; Buschmann et al., 2001, 2008; Reid et al., 2013), since algae require access to ample levels of solar irradiance at the ocean surface. A 100 ha Gracilaria (seaweed) farm can theoretically remove $80 \%$ of the dissolved nitrogen released by a 1,500 ton salmon farm (Buschmann et al., 2008; Abreu et al., 2009). However, it is not known how dissolved nutrients are dispersed within a farm occupying a large area and this will require further studies. From a relatively large sized salmon farm $(>1,500$ ton) it has been shown that nutrients released may enhance seaweed growth as far as a kilometer from the farm (Abreu et al., 2009).

Nutrient enhancement through intensive aquaculture can lead to a change in biodiversity and abundance of microalgae (Froehlich et al., 2017b; Glibert, 2017; Glibert and Burford, 2017). This or other factors, such as global warming, could lead to an increase in harmful algal blooms (HABs) (Burkholder et al., 2008; Berdalet et al., 2014; Gobler et al., 2017). In turn, HABs can be toxic to marine species (Landsberg, 2002). One of the many risks to coastal aquaculture are HABs as they can cause mortalities for the farmed species, predominantly fish, and infections through biotoxins via shellfish consumption, such as Diarrhetic Shellfish Poisoning (DSP), Paralytic Shellfish Poisoning (PSP); Neurotoxic Shellfish Poisoning (NSP), and Amnesic Shellfish Poisoning (ASP). In some areas, HABs can be linked to anthropogenic influences through e.g., urban sewage and agriculture-induced nutrient-rich river-run offs (Gowen et al., 2012), however, other blooms originate naturally, e.g., due to El Niño events. After a severe algal bloom in 2016, Chilean aquaculture experienced extreme mortalities of $\sim 40$ million farmed salmons, which caused a financial loss of US $\$ 800$ million (Apablaza et al., 2017). As those blooms are spatially and temporally variable early warning systems are needed to allow best management for the cultured species (transfer of fish cages to "safe" areas, harvest before HABs appear or delay shellfish harvest until toxins depurate). With regard to offshore aquaculture, the relationship between nutrient alterations, HABs and aquaculture operations needs further investigations (Kamermans et al., 2011). There is a need for new assessment methods and effective monitoring to verify the effects of aquaculture in the offshore realm.

The need for extensive surface area also has to be considered for farms placed within offshore wind farm areas, as service and maintenance vessels need to have easy access to the wind turbines. A site plan with declared "aquaculture fields" will be of prime importance (Figure 7) to allow the operation of the two uses, wind farms and aquaculture. Due to these extensive area demands, seaweed installations are likely to be part of marine spatial planning (MSP) development as navigation is concerned, whereas farming of bivalves or fish can be conducted at greater depths with less surface requirements.

\section{BASIC CONSIDERATIONS FOR SOCIO-ECONOMIC AND ECONOMIC FEASIBILITY}

To date, it can be observed that the scientific community has generally focussed aquaculture research on technological 


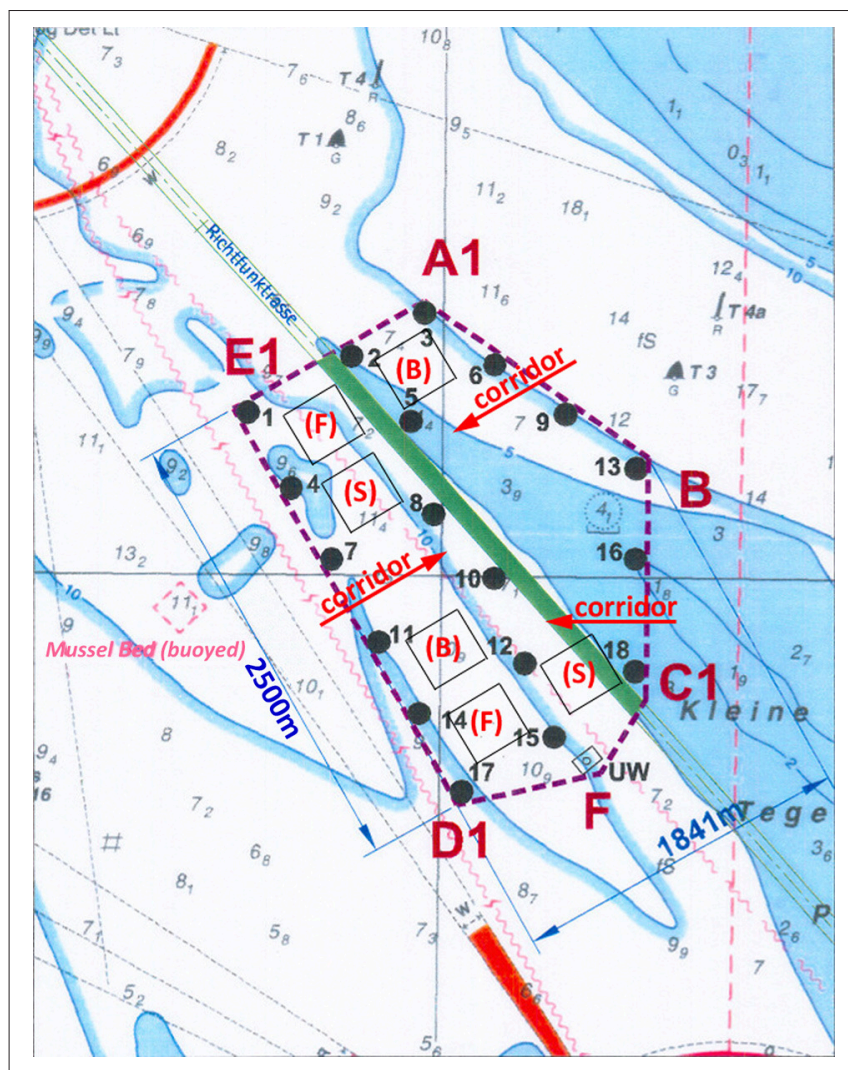

FIGURE 7 | Map of the offshore wind farm Nordergründe $\sim 17$ nautical miles off the coast from the city of Bremerhaven (North Germany). This figure shows a bird's eye view displaying 18 offshore wind turbines (numbers without brackets) and six single aquaculture plots (numbers with brackets) designated by the wind farm company. All six designated plots were declared for IMTA, including fish cultivation (F), seaweed cultivation (S), and bivalve (mussel) cultivation (B). Black arrows indicated corridors for vessels to enter the wind farm area to service turbines, which are located in the center of the wind farm area (Image with permission of the publisher modified after Buck et al., 2017b).

and environmental issues (Marra, 2005). Over the course of the last years, it became evident that the "social license to operate," reflecting continuous acceptance, is a central item in the future development of the aquaculture sector (SAPEA, 2017). Indeed, aquaculture offers a variety of socio-economic benefits through the supply of highly nutritious foods and commercially valuable products, providing jobs and creating income, especially in remote areas (FAO, 2012, 2014; ICES, 2012; Krause et al., 2015). For instance, it could be observed in South Africa that the employment of a large number of unskilled and semi-skilled personnel in the aquaculture sector had a large local socio-economic positive impact in coastal communities with traditionally high-unemployment rates (Troell et al., 2006; Nobre et al., 2010). In addition to its direct economic contribution, aquaculture has added socio-economic value in that it generates additional employment and income in the form of spinoff and support industries that deal with marketing, supply, product distribution, processing, packaging, etc. (ICES, 2012). It has been estimated that, for each person employed in aquaculture production, about three others are employed in secondary and related activities (Buchholz et al., 2012; Krause et al., 2015). However, there are also examples of aquaculture causing negative social impacts due to lack of local and regional planning and failure to fully understand how the aquaculture activity is interlinked to and affects natural systems and people depending on these (Krause et al., 2015). Thus, this multitude of potential secondary socio-economic effects shifts the assessment of aquaculture beyond neoclassical economic input-output analysis.

\section{Planning and Management Considerations}

As a novel and yet emerging approach to seafood production, IMTA is challenged by the need to prove and justify itself not only in term of environmental benefits but also in terms of economic and social viability. Indeed, the contemporary aquaculture sector, as well as decision-makers and other stakeholders remain to be convinced that IMTA not only works but that it is also sustainable (Krause et al., 2011). Because this concept is new and unproven in the western world (for Asia-see Troell et al., 2009), various questions have been raised regarding not only its biological feasibility but also its economic viability. Additionally, the changing marine utilization patterns represent considerable challenges to governance and management, vis à vis acceptance within society and different political levels. Next to the central questions of liability and who "owns" the oceans (Krause et al., 2011), which are subject to intense competition leading inevitably to disputes, very practical issues related to facility management, potential market chains and revenue flow considerations need to also be addressed. For the former, the factual situation of private ownership of ocean space by novel lines of production fosters "client mentalities" of ocean pioneers, such as the yet emerging offshore wind farm industry. This stands in contrast to the negotiations conducted under the umbrella of The UNCLOS to develop an international legally binding instrument on the conservation and sustainable use of marine biological diversity of areas beyond national jurisdiction. The current observed "client mentalities" of offshore users, however, leave little room for such efforts to be successfully effected and adhered. Furthermore, scope and instruments for a broader participation and collaboration to harness the potential benefits of other novel industries such as IMTA that could be co-developed are lacking. However, from a socio-economic perspective, broader participation strategy of its implementation would be favorable, since several different forms of seafood products are generated in the same area, each facing different issues in terms of technology, biology, markets but also shares of socio-economic benefits to the participating actors. These so-called "productive interactions" of different spheres of knowledge are central here, since so far the experience of IMTA is limited, especially in terms of scope and set-up to become commercially robust and viable. Thus, collaborative efforts may provide creative avenues to investigate further the potential role of IMTA within the context of future developments of aquaculture in the offshore realm, whilst at the same time, providing room to create local ownership of decision-making processes that improve the social license to operate. 


\section{Operation and Maintenance Considerations}

From a social stance, improvement in public acceptability of the aquaculture industry (and also the wind farm industry, by reducing their combined footprint), and the potential creation of additional jobs, income protection through diversification and access to new markets may create positive long-term outcomes for IMTA and the aquaculture sector in general. However, to this end, especially at IMTA operations, personnel with a wide range of skills are required. This is due to the fact that very different species with different rearing and maintenance demands are jointly cultured. Therefore, next to the supplementary costs such as for infrastructure, developing knowledge by training, developing different marketing strategies for the respective species, as well as different operation modes to produce the co-cultured species must be considered.

\section{Economic Considerations}

Economic value chains are becoming increasingly global, thus resulting in a growing interconnectedness of economies and fragmentation of economic activities across countries worldwide. Today, more than half of the world's imports and exports of intermediate goods, include value added features from abroad in which different firms and countries have specialized in specific functions and tasks. This observed share of economic value chains can be viewed as means of increasing productivity and competitiveness while also holding the potential of affecting local labor markets, mainly by affecting demand for different skills groups (OECD, 2013).

In our case, the likely occurrence of higher costs for main inputs like energy and feeds entails that the profitability of offshore aquaculture may be further reduced. Through the lens of global value chains, these costs can be brought down by looking at relative costs and factor endowments. Indeed, scope to build an efficient value chain across firms and locations may occur if offshore IMTA will be teamed in co-use scenarios with other actors, such as wind farming or oil and gas platforms, which enable companies to benefit from the economies of scale and scope that other specialized industries can provide. Opportunities of additional cost savings could decrease shipping costs, improve maintenance and education as well as allow combined environmental impact assessments and permitting procedures (Buck et al., 2010; Kite-Powell, 2017). However, even in a well-balanced co-management concept, such innovative enterprises are still cost-intensive in comparison to nearshore aquaculture.

Hence, the economic value of seafood production in IMTA on the market may vary, depending on what species are cultured, e.g., readily usable for human consumption or focusing on industrial applications. Nonetheless, potential scope exists for some species to be used as feeds or as a source of essential marine oils and e.g., mussel meal (Weiß and Buck, 2017) to replace the heavy reliance of intensive aquaculture on wild fish populations. This may lead to a reduction of the marine footprint of these aquaculture systems. Conversely, the economic success of IMTA is not only determined by income at the point of sale. Net profits are the integrated outcome related to costs of initial investment, maintenance, harvesting, handling, and other costs associated with production, including marketing efforts. A diversified product portfolio will increase the resilience of aquaculture in the face of disease, product gluts, and price fluctuations in one of the farmed species (but not in the event that the whole farm is damaged by a severe storm). In such situations, product diversification may increase the survivability of the entire IMTA enterprise. This will only be the case if the products do not differ too much in value, i.e., if the most valuable species crashes, the remaining products must be able to sustain the farm (in terms of profit) in times of crisis.

A further central challenge of current large-scale fish aquaculture operations in cages is to date their low profit margins. This may impede the further development of offshore fish farming. With respect to IMTA, a key question will, therefore, be how and how much the extractive aquaculture co-products will contribute to the overall economic performance of offshore IMTA systems. For each species cultured, different markets exist with different demands, potentials and constraints, all of which add to the likelihood of increasing costs before revenues are generated. However, in a broader and more long-term perspective, IMTA has the potential to provide ecosystem services and benefits not only at the farm level but rather at broader environmental and societal levels. From an environmental and resource perspective, such broader benefits include reduction in waste discharges that lessen negative environmental impacts, and improved utilization of resources.

\section{Internal Economic Considerations}

At the direct farm level, the primary benefits are obtained through the maximization of the net income, including the additional profit from the production of additional extractive species that capture different (niche) markets. Whereas seaweeds generally have a low market price, they are profitable when considering the millions of tons produced annually (mainly in Asia) (Chopin and Sawhney, 2009). Furthermore, the value of seaweeds is rising globally as the western world realizes their contribution to health (see also SAPEA, 2017). The profitability of seaweed production in offshore IMTA farms may be enhanced by the cultivation of species that are both effective nutrient biofilters and have added value, e.g., sea-vegetables, nutraceuticals and cosmetics, or species providing future basis for Integrated Sequential BioRefinery (ISBR) production (Chopin et al., 2011). The identification of higher value products and extracts from macroalgae will serve as an added argument in support of their production in IMTA systems. For instance, Macrocystis, a low-value genus harvested for its alginates, has recently been used in higher valued edible products, and as organic feed for abalone (Gutiérrez et al., 2006; Flores-Aguilar et al., 2007). The utilization of seaweeds for aquafeeds is an emergent research priority for the aquaculture industry, and this may act as an additional convincing point to the industry to deploy IMTA systems. The concept of nutrient trading credits could maybe be a worthwhile avenue to consider (Chopin, 2012). Indeed, the role of ecosystem services within the IMTA approach is being increasingly recognized and their values estimated 
(Millennium Ecosystem Assessment, 2005; TEEB, 2010; Chopin, 2018b). Although it is difficult to estimate the economic value (for society) of the degradation of the environment, there is clearly a benefit in mitigation of eutrophication, via IMTA extractive species, as well as improving resource utilization. Information on nutrient mitigation benefits in offshore environments is scarce, but needs to be addressed. Using an ecosystem approach to aquaculture will allow for broader planning, that includes multiple stakeholder perspectives and identification of all potential trade-offs (FAO, 2012, 2016).

The production of seaweed and mussel in offshore IMTA may, however, be lucrative independently. If the extractive performance can be translated into additional positive economic returns for the farmer, this would create powerful incentives for integration under one umbrella. To be able to capture these benefits it will be necessary to: (1) determine and quantify the environmental costs and externalities from cultivating fed species (i.e., fish), and (2) develop economic frameworks for internalizing positive outcomes of the integration of extractive organisms. For example, a program was developed for Swedish mussel farmers, wherein farmers got credits to offset nutrient [carbon $(\mathrm{C})$, nitrogen $(\mathrm{N})$, and phosphorus $(\mathrm{P})$ ] discharges (e.g., from sewage outfalls) (Lindahl et al., 2005; Lindahl, 2011). This raises, however, the question-how relevant is this payment for offset in offshore areas? Moreover, who will be the institutions making the financial credit transactions?

Gross profit from an offshore kelp (S. latissima) farm (based on production data) was US $\$ 52 \mathrm{yr} /$ culture unit, whereas overall investment was US $\$ 130 \mathrm{yr} /$ culture unit (Buck and Buchholz, 2004). The relatively high investment cost (as compared to seaweed farming in nearshore waters) was due to the need to establish a farm infrastructure and to choose a species that could survive the harsh offshore conditions. It is important to note that labor, operation, and maintenance costs were not included in this analysis. Data on offshore seaweed farming (S. latissima) integrated into an offshore wind farm revealed that the overall costs could be reduced, resulting in a cost-effective enterprise (Griffin et al., 2015). Buck et al. (2012) supported this analysis by providing a list of potential cost saving measures in a seaweedwind farm enterprise. For instance, integrating extractive species such as seaweeds and shellfish with offshore fish farms could benefit from other present structures [e.g., wind farms (Buck, 2007) or single point mooring cage systems to which extractive species units can be attached], whereas technological innovation will be needed to make these designs economically feasible. The IMTA systems currently being used in Canada and China are relatively simple and are based on ropes and rafts for relatively sheltered sites, not highly exposed offshore environments, for which a different approach will be needed.

\section{Externalities}

Offshore farming systems may be competitive with nearshore farms by their ability to capitalize on economies of scale, as offshore farms will not be subjected to the same size limitations. Additionally, costs could be reduced when operating offshore farms in co-use with other stakeholders, such as renewable energy installations (wind, solar, wave, current, tide) or oil/gas platforms. Indeed, the current development has shown that in the case of the offshore wind farm industry, the sector has moved out of their nascent status and is moving toward a robust and stable sector. However, it should be taken into account that the multi-use combination with oil and gas rigs could lead to a risk of contamination of aquaculture products for human consumption by any release of leaching products or other substances originating from the operation of oil and gas rigs, which in turn could lead to a reduced acceptance of the product by any user or consumer.

Further strengthening of institutional resources and capacity (containing human capacity), mutually at national and international levels, are required to allow the development of offshore IMTA for sustainable livelihoods and as an avenue for maintaining food security in the future. To reach this goal requires further innovation; novel feed development is a case in point in this context. Indeed, IMTA holds the potential to take an increased role for global food security, especially if looking at extractive species. Additionally, a critical but often overlooked question pertains to how to best guide the development of aquaculture that has the potential to support a portfolio of alternative livelihoods, especially in coastal regions under transition (Krause et al., 2015).

\section{CONCLUSION}

Further increase of marine aquaculture production will probably involve expansion into more exposed oceanic locations, but to what extent is uncertain. Marine aquaculture may also expand further on land in recirculating aquaculture systems (RAS). Moving offshore is one way to reduce coastal stakeholder conflicts, environmental concerns, and to access better water quality. However, the solution to pollution should not be dilution but wastes should instead be seen as resources. It is most likely that offshore farms will be much larger than current coastal farms resulting in significantly more wastes being generated at each farm site. These wastes should be seen as co-products and resources to be utilized in a circular economy framework. It could be anticipated that even offshore farms could exceed the environmental assimilative capacity if increasing in size. There is, however, limited understanding regarding the links between offshore and coastal oceanic processes and, therefore, scientific research should closely accompany the development of offshore aquaculture and IMTA. IMTA may provide an alternative for making use of waste products and transforming these into valuable co-products, while, in addition to increased product profitability, other benefits and services may also be generated by the integrated extractive species. Existing methods for farming extractive species, like seaweeds and invertebrates, in coastal and sheltered areas need to be modified for offshore operations to be able to withstand drag forces from strong currents, waves and swell typical of more exposed environments. While it is likely that higher growth rates will be recorded in the vicinity of offshore fish farms, there is also a need to identify risks (e.g., social, economic, and environmental) and to understand and communicate the bioremediative roles of extractive species. Employing IMTA within multiple-use offshore systems has the potential to provide 
commercially valuable organisms representing different trophic levels, and a variety of ecosystem services, that could sustain each other and participate in the bioremediation and protection of the marine environment, whilst providing a sustainable avenue for future food production from the oceans.

\section{AUTHOR CONTRIBUTIONS}

$\mathrm{BB}$ and MT wrote most parts of the manuscript, however, the paper was of course then jointly developed during the last months and years with valuable inputs, experience, and participation of the other authors. All authors read and approved the final manuscript.

\section{REFERENCES}

Abreu, M. L., Varela, D. A., Henríquez, L., Villarroel, A., Yarish, C., Sousa-Pinto, I., et al. (2009). Traditional vs. integrated multi-trophic aquaculture of Gracilaria chilensis. C. J. Bird, J. McLachlan \& E.C. Oliveira: productivity and physiological performance. Aquaculture 293, 211-220. doi: 10.1016/j.aquaculture.2009.03.043

Alston, D. E., Cabarcas, A., Capella, J., Benetti, D. D., Keene-Meltzoff, S., Bonilla, J., et al. (2005). Environmental and Social Impact of Sustainable Offshore Cage Culture Production in Puerto Rican Waters. Washington, DC: NOAA.

Apablaza, P., Frisch, K., Brevik, Ø. J., Småge, S. B., Vallestad, C., Duesund, H., et al. (2017). Primary Isolation and Characterization of Tenacibaculum maritimum from Chilean Atlantic Salmon Mortalities Associated with a Pseudochattonella spp. algal bloom. J. Aquat. Anim. Health 29, 143-149. doi: 10.1080/08997659.2017.1339643

Aquaculture Planning and Advocacy (2009). Final Environmental Assessment, Proposed Expansion of Hukilau Foods Offshore Fish Farm, Mamala Bay, Oahu, Hawaii. Kaneohe, HI: Aquaculture Planning and Advocacy.

Bakken, P. (2013). "Seaweed to bio-fuels future direction," in International Seaweed Symposium (Bali).

Bartsch, A., Robinson, S. M., Liutkus, M., Ang, K. P., Webb, J., and Pearce, C. M. (2013). Filtration of sea louse (Lepeophtheirus salmonis) copepodids by the blue mussel (Mytilus edulis) and the Atlantic sea scallop (Placopecten magellanicus) under different flow, light and copepodid-density regimes. J. Fish Dis. 36, 361-370. doi: 10.1111/jfd.12069

Berdalet, E., McManus, M. A., Ross, O., Burchard, H., Chavez, F. P., Jaffe, J., et al. (2014). Understanding harmful algae in stratified systems: review of progress and future directions. Deep Sea Res. 101, 4-20. doi: 10.1016/j.dsr2.2013. 09.042

Brenner, M., and Buck, B. H. (2010). Attachment properties of blue mussels (Mytilus edulis L.) byssus threads on culture-based artificial collector substrates. Aquacult. Eng. 42, 128-139. doi: 10.1016/j.aquaeng.2010.02.001

Brenner, M., Buchholz, C., Heemken, O., Buck, B. H., and Koehler, A. (2012). Health and growth performance of blue mussels (Mytilus edulis L.) from two different hanging cultivation sites in the German Bight: a nearshore - offshore comparison. Aquacult. Int. 20, 751-778. doi: 10.1007/s10499-012-9501-0

Bridger, C. J., and Costa-Pierce, B. A. (2003). Open Ocean Aquaculture: From Research to Commercial Reality. New York, NY; Baton Rouge, LA: World Aquaculture Society; Academic Press.

Buchholz, C., Krause, G., and Buck, B. H. (2012). "Seaweed and man," in Seaweed Biology: Novel Insights into Ecophysiology, Ecology and Utilization, eds C. Wiencke and K. Bischof (Heidelberg; Berlin: Springer), 471-493.

Buck, B. H. (2002). Open Ocean Aquaculture und Offshore Windparks. Eine Machbarkeitsstudie über die multifunktionale Nutzung von OffshoreWindparks und Offshore-Marikultur im Raum Nordsee, Reports on Polar and Marine Research, Alfred Wegener Institute for Polar and Marine Research, Bremerhaven, 252.

Buck, B. H. (2004). Farming in a High Energy Environment: Potentials and Constraints of Sustainable Offshore Aquaculture in the German Bight (North

\section{ACKNOWLEDGMENTS}

The research was funded by various funding bodies. Most funding was received by the German Federal Ministry of Food and Agriculture (No. 313-06.01-28-1-73.009-10), the German Federal Ministry for the Environment, Nature Conservation, Building and Nuclear Safety (No. 0325206), the German Federal Ministry of Education and Research (No. 03F0404A, 03F0404B, 03F0404C, 03F0404D), and the Senator for Environment, Construction and Transportation Bremen (Germany) (No. FV 168 and No. FV 174). Finally, we would like to thank the reviewers for their valuable comments, which led to an improvement of manuscript's quality.

Sea). Ph.D. thesis, Alfred Wegener Institute for Polar and Marine Research Bremerhaven, Bremen: University of Bremen.

Buck, B. H. (2007). Experimental trials on the feasibility of offshore seed production of the mussel Mytilus edulis in the German Bight: installation, technical requirements and environmental conditions. Helgoland Mar. Res. 61, 87-101. doi: 10.1007/s10152-006-0056-1

Buck, B. H., and Buchholz, C. M. (2004). The offshore-ring: a new system design for the open ocean aquaculture of macroalgae. J. Appl. Phycol. 16, 355-368. doi: 10.1023/B:JAPH.0000047947.96231.ea

Buck, B. H., and Buchholz, C. M. (2005). Response of offshore cultivated Laminaria saccharina to hydrodynamic forcing in the North Sea. Aquaculture 250, 674-691. doi: 10.1016/j.aquaculture.2005.04.062

Buck, B. H., and Grote, B. (2018). "Seaweed in high energy environments: protocol to move Saccharina cultivation offshore," in Protocols for Macroalgae Research, eds B. Charrier, T. Wichard, C. R. K. Reddy (Boca Raton, FL: CRC Press; Taylor \& Francis Group), 3-36.

Buck, B. H., and Krause, G. (2012). "Chapter 180: Integration of aquaculture and renewable energy systems," in Encyclopedia of Sustainability Science and Technology, ed R. E. Meyers (Springer Science Business Media, LLC), 511-533.

Buck, B. H., and Langan, R. (2017). Aquaculture Perspective of Multi-Use Sites in the Open Ocean: The Untapped Potential for Marine Resources in the Anthropocene. Cham: Springer.

Buck, B. H., Berg-Pollack, A., Assheuer, J., Zielinski, O., and Kassen, D. (2006). "Technical realization of extensive aquaculture constructions in offshore wind farms: consideration of the mechanical loads," in Proceedings of the 25th International Conference on Offshore Mechanics and Arctic Engineering, OMAE 2006: Presented at the 25th International Conference on Offshore Mechanics and Arctic Engineering, Hamburg, Germany/sponsored by Ocean, Offshore, and Arctic Engineering, ASME (New York, NY: American Society of Mechanical Engineers), 1-7.

Buck, B. H., Dubois, J., Ebeling, M., Franz, B., Goseberg, N., Krause, G., et al. (2012). Projektbericht Multiple Nutzung und Co-Management von OffshoreStrukturen: Marine Aquakultur und Offshore Windparks - Open Ocean Multi-Use (OOMU). Gefördert durch das BMU - Förderkennzeichen 325206. Projektleitung: IMARE GMBH Bremerhaven.

Buck, B. H., Ebeling, M., and Michler-Cieluch, T. (2010). Mussel cultivation as a co-use in offshore wind farms: potentials and economic feasibility. Aquacult. Econ. Manage. 14, 1365-7305. doi: 10.1080/13657305.2010.526018

Buck, B. H., Krause, G., and Rosenthal, H. (2004). Extensive open ocean aquaculture development within wind farms in Germany: the prospect of offshore co-management and legal constraints. Ocean Coast. Manag. 47, 95-122. doi: 10.1016/j.ocecoaman.2004.04.002

Buck, B. H., Krause, G., Michler-Cieluch, T., Brenner, M., Buchholz, C. M., Busch, J. A., et al. (2008a). Meeting the quest for spatial efficiency: progress and prospects of extensive aquaculture within offshore wind farms. Helgoland Mar. Res. 62, 269-281. doi: 10.1007/s10152-0080115-x

Buck, B. H., Krause, G., Pogoda, P., Grote, B., Wever, L., Goseberg, N., et al. (2017a). "Case study German Bight: pioneer projects of aquaculture-wind farm 
multi-uses," in Aquaculture Perspective of Multi-Use Sites in the Open Ocean: The Untapped Potential for Marine Resources in the Anthropocene, eds B. H. Buck and R. Langan (Cham: Springer), 253-354.

Buck, B. H., Nevejan, N., Wille, M., Chambers, M., and Chopin, T. (2017b). "Offshore and multi-use aquaculture with extractive species: seaweeds and bivalves," in Aquaculture Perspective of Multi-Use Sites in the Open Ocean: The Untapped Potential for Marine Resources in the Anthropocene, eds B. H. Buck and R. Langan, 23-69.

Buck, B. H., Thieltges, D. W., Walter, U., Nehls, G., and Rosenthal, H. (2005). Inshore-offshore comparison of parasite infestation in Mytilus edulis: implications for open ocean aquaculture. J. Appl. Ichthyol. 21, 107-113. doi: 10.1111/j.1439-0426.2004.00638.x

Buck, B. H., Zielinski, O., Assheuer, A., Wiemann, K., Hamm, C., and Kassen, D. (2008b). Technical Realisation of Extensive Mariculture Systems within Offshore Wind Farms: Betrachtung of the Mechanical Loads. Project report FV 174, funded by the SBUV of the City of Bremen. Alfred Wegener Institute Helmholtz Centre for Polar and Marine Research (AWI).

Bugrov, L. (1992). Rainbow trout culture in submersible cages near offshore oil platforms. Aquaculture 100, 169. doi: 10.1016/0044-8486(92)90359-S

Bugrov, L. (1996). "Underwater fish-farming technology for open sea areas: review of a 10-year experience," in Open Ocean Aquaculture (Portland: New Hampshire/Maine Sea Grant College Program), UNHMP-CP-SG-96-9, 269-296.

Burkholder, J. M., Glibert, P. M., and Skelton, H. (2008). Mixotrophy, a major mode of nutrition for harmful algal species in eutrophic waters. Harmful Algae 8, 77-93. doi: 10.1016/j.hal.2008.08.010

Buschmann, A. H., Mora, O., Gómez, P., Böttger, M., Buitano, S., Retamales, C. A., et al. (1994). Gracilaria chilensis outdoor tank cultivation in Chile: use of land-based salmon culture effluents. Aquacul. Eng. 13, 283-300. doi: 10.1016/0144-8609(94)90016-7

Buschmann, A. H., Retamales, C., and Figueroa, C. (1997). Ceramialean epiphytism in an intertidal Gracilaria chilensis (Rhodophyta) bed in southern Chile. J. Appl. Phycol. 9, 129-135. doi: 10.1023/A:10079716 15801

Buschmann, A. H., Varela, D. A., Hernández-González, M. C., and Huovinen, P. (2008). Opportunities and challenges for the development of an integrated seaweed- based aquaculture activity in Chile: determining the physiological capabilities of Macrocystis and Gracilaria as biofilters. J. Appl. Phycol. 20, 571-577. doi: 10.1007/s10811-007-9297-x

Buschmann, A., Troell, M., and Kautsky, N. (2001). Integrated algal farming: a review. Cahiers Biol. Mar. 42, 83-90.

Carrington, E., Grace, S. P., and Chopin, T. (2001). Life history phases and the biomechanical properties of the red alga Chondrus crispus (Rhodophyta). J. Phycol. 37, 699-704. doi: 10.1046/j.1529-8817.2001.00169.x

Chambers, M. D. (2013). Integrated multi-trophic Aquaculture of Steelhead, Blue Mussels and Sugar Kelp, Ph.D. dissertation. Department of Biological Sciences, University of New Hampshire, Durham, NH.

Cheshuk, B. W., Purser, G. J., and Quintana, R. (2003). Integrated open-water mussel (Mytilus planulatus) and Atlantic salmon (Salmo salar) culture in Tasmania, Australia. Aquaculture 218, 357-378. doi: 10.1016/S0044-8486(02)00640-3

Chopin, T. (2011). Progression of the Integrated Multi-Trophic Aquaculture (IMTA) concept and upscaling of IMTA systems towards commercialization. Aquacult. Europe 36 , 5-12.

Chopin, T. (2012). Seaweed aquaculture provides diversified products, key ecosystem functions. Part II. Recent evolution of seaweed industry. Glob. Aquacul. Advocate 15, 24-27.

Chopin, T. (2018a). Seaweed aquaculture - From the global, mostly Asian, picture to the opportunities and constraints of the Canadian scene. Bull. Aquacult. Assoc. Canada 2017-1, 3-8.

Chopin, T. (2018b). The renewed interest in the cultivation of seaweeds, as the inorganic extractive component of Integrated Multi-Trophic Aquaculture (IMTA) systems, and for the ecosystem services they provide. Bull. Aquacult. Assoc. Canada 2017-1, 13-18.

Chopin, T., and Sawhney, M. (2009). "Seaweeds and their mariculture," in The Encyclopedia of Ocean Sciences, eds J. H. Steele, S. A. Thorpe, and K. K. Turekian (Oxford: Elsevier), 4477-4487.
Chopin, T., Buschmann, A., Halling, C., Troell, M., Kautsky, N., Neori, A., et al. (2001). Integrating seaweeds into aquaculture systems: a key towards sustainability. J. Phycol. 37, 975-986. doi: 10.1046/j.1529-8817.2001.01137.x

Chopin, T., Neori, A., Buschmann, A., Pang, S., and Sawhney, M. (2011). Diversification of the aquaculture sector: Seaweed cultivation, integrated multi-trophic aquaculture, integrated sequential biorefineries. Glob. Aquacult. Advocate 14, 58-60.

Chopin, T., Robinson, S. M. C., Troell, M., Neori, A., Buschmann, A. H., and Fang, J. (2008). "Multitrophic integration for sustainable marine aquaculture," in The Encyclopedia of Ecology, Ecological Engineering, Vol. 3, eds S. E. Jørgensen and B. D. Fath . (Oxford: Elsevier), 2463-2475.

Chopin, T., Robinson, S., Reid, G., and Ridler, N. (2013). Prospects for Integrated Multi-Trophic Aquaculture (IMTA) in the open ocean. Bull. Aquacult. Assoc. 111-2, 28-35.

Chopin, T., Robinson, S., Sawhney, M., Bastarache, S., Belyea, E., Shea, R., et al. (2004). The AquaNet integrated multi-trophic aquaculture project: rationale of the project and development of kelp cultivation as the inorganic extractive component of the system. Bull. Aquacult. Assoc. Canada 104, 11-18.

Corbin, J. (2007). Marine aquaculture: today's necessity for tomorrow's seafood. Mar. Technol. Soc. J. 41, 16-23.

Cranford, P. J., Reid, G. K., and Robinson, S. M. C. (2013). Open water integrated multi-trophic aquaculture: constraints on the effectiveness of mussels as an organic extractive component. Aquacult. Environ. Interact. 4, 163-173. doi: 10.3354/aei00081

Dalton, R. (2004). Fishing for trouble. Nature 431, 502-504. doi: 10.1038/431502a

Danioux, C., Bompais, X., Paquotte, P., and Loste, C. (2000). "Offshore mollusc production in the Mediterranean Basin," in Mediterranean Offshore Mariculture, eds J. Muir and B. Basurco (Zaragoza: CIHEAM), 115-140.

Delbare, D. (2001). Pesca-project: Hangmosselcultuur in Belgische Kustwateren. Centrum voor Landbouwkundig Onderzoek-Gent. Departement Zeevisserij afdeling Aquacultuur en Restocking.

Dempster, T., Sanchez-Jerez, P., Bayle- Sempere, J. T., Giménez-Casalduero, F., and Valle, C. (2002). Attraction of wild fish to sea-cage fish farms in the southwestern Mediterranean Sea: spatial and short-term temporal variability. Mar. Ecol. Prog. Ser. 242, 237-252. doi: 10.3354/meps 242237

Ekau, W., Auel, H., Pörtner, H.-O., and Gilbert, D. (2010). Impacts of hypoxia on the structure and processes in pelagic communities (zooplankton, macro-invertebrates and fish). Biogeosciences 7, 1669-1699. doi: 10.5194/bg-7-1669-2010

FAO (2006). State of World Aquaculture. FAO Fisheries Technical Paper. No. 500. Rome: FAO.

FAO (2012). The State of World Fisheries and Aquaculture 2012. Rome: FAO.

FAO (2014). The State of World Fisheries and Aquaculture 2014. Rome: FAO.

FAO (2016). The State of World Fisheries and Aquaculture 2016. Rome: FAO.

Ferreira, J. G., Sequeira, A., Hawkins, A. J. S., Newton, A., Nickell, T. D., Pastres, R., et al. (2009). Analysis of coastal and offshore aquaculture: application of the FARM model to multiple systems and shellfish species. Aquaculture 292, 129-138. doi: 10.1016/j.aquaculture.2009.03.039

Fletcher, R. L. (1995). Epiphytism and fouling in Gracilaria cultivation: an overview. J. Appl. Phycol. 7, 325-333. doi: 10.1007/BF00004006

Flores-Aguilar, R. A., Gutierrez, A., Ellwanger, A., and Searcy-Bernal, R. (2007). Development and current status of abalone aquaculture in Chile. J. Shellfish Res. 26, 705-707. doi: 10.2983/0730-8000(2007)26[705:DACSOA]2.0.CO;2

Folke, C., Kautsky, N., and Troell, M. (1994). The costs of eutrophication from salmon farming: implications for policy. J. Environ. Manage. 40, $173-182$.

Fredriksson, D., Tsukrov, W., and Hudson, P. (2008). Engineering investigation of design procedures for closed containment marine aquaculture systems. Aquacult. Eng. 39, 91-102. doi: 10.1016/j.aquaeng.2008.08.002

Friedlander, M., Krom, M. D., and Ben-Amotz, A. (1991). The effect of light and ammonium on growth, epiphytes and chemical constituents of Gracilaria conferta in outdoor cultures. Bot. Mar. 34, 161-166. doi: 10.1515/botm.1991.34.3.161

Froehlich, H. E., Gentry, R. R., Rust, M. B., Grimm, D., and Halpern, B. S. (2017a). Public perceptions of aquaculture: evaluating spatiotemporal patterns of sentiment around the world. PLoS ONE 12:e0169281. doi: 10.1371/journal.pone.0169281 
Froehlich, H. E., Smith, A., Gentry, R. R., and Halpern, B. S. (2017b). Offshore aquaculture: $\mathrm{i}$ know it when i see it. Front. Mar. Sci. 4:154.doi: $10.3389 /$ fmars.2017.00154

Ganesan, M., Thiruppathi, S., Sahu, N., Rengarajan, N., Veeragurunathan, V., and Jha, B. (2006). In situ observations on preferential grazing of seaweeds by some herbivores. Curr. Sci. 91, 1256-1260.

Gaylord, B., Denny, M. W., and Koehl, M. A. R. (2008). Flow forces on seaweeds: field evidence for roles of wave impingement and organism inertia. Biol. Bull. 215, 295-308. doi: 10.2307/25470713

Gentry, R. R., Froehlich, H. E., Grimm, D., Kareiva, P., Parke, P., Rust, M., et al. (2017). Mapping the global potential for marine aquaculture. Nat. Ecol. Evol. 1, 1317-1324. doi: 10.1038/s41559-0170257-9

Gimpel, A., Stelzenmüller, V., Grote, B., Núñez-Riboni, I., Buck, B. H., Pogoda, B., et al. (2015). Evaluating the co-use of offshore wind farms and aquaculture in the German EEZ - a GIS modelling approach. Mar. Policy 55, 102-115.

Glibert, P. (2017). Eutrophication, harmful algae and biodiversity - Challenging paradigms in a world of complex nutrient changes. Mar. Pollut. Bull. 124, 591-606. doi: 10.1016/j.marpolbul.2017.04.027

Glibert, P. M., and Burford, M. A. (2017). Globally changing nutrient loads and harmful algal blooms: recent advances, new paradigms, and continuing challenges. Oceanography 30, 58-69. doi: 10.5670/oceanog. 2017.110

Gobler, C. J., Doherty, O. M., Hattenrath-Lehmann, T. K., Griffith, A. W., Kang, Y., and Litaker, R. W. (2017). Ocean warming since 1982 has expanded the niche of toxic algal blooms in the North Atlantic and North Pacific oceans. Proc. Natl. Acad. Sci. U.S.A. 114, 4975-4980. doi: 10.1073/pnas.16195 75114

Gowen, R. J., McKinney, A., Tett, P., Bresnan, E., Davidson, K., Harrison, P. J., et al. (2012). Anthropogenic nutrient enrichment and blooms of harmful phytoplankton. Oceanogr. Mar. Biol., 50: 65-126. doi: 10.1201/b12 157-3

Granada, L., Sousa, N., Lopes, S., and Lemos, M. F. L. (2016). Is integrated multitrophic aquaculture the solution to the sectors' major challenges? - a review. Rev Aquacult. 8, 283-300. doi: 10.1111/raq.12093

Griffin, R., Krause, K., and Buck, B. H. (2015). Co-production as a policy for marine spatial planning: the case of offshore wind energy and aquaculture. Aquaculture 436, 80-89.

Grote, B. (2016). Bioremediation of aquaculture wastewater: evaluating the prospects of the red alga Palmaria palmata (Rhodophyta) for nitrogen uptake. J. Appl. Phycol. 28, 3075-3082. doi: 10.1007/s10811-016-0848-x

Grote, B., Pogoda, B., and Buck, B. H. (2013a). "The IMTA-approach in the German EEZ: Evaluating the potential within offshore wind farms," in Aquaculture Conference: To the Next 40 Years of Sustainable Global Aquaculture (Las Palmas).

Grote, B., Strieben, S., and Buck, B. H. (2013b). "Integrated multi-trophic aquaculture in the north sea: preliminary studies for moving off the coast," in Offshore-Site-Selection - Aquakultur Site Selection für die Nachhaltige und Multifunktionale Nutzung von Marinen Gebieten in stark genutzten Meeren am Beispiel der Nordsee, eds B. Grote, M. Ebeling, U. Focken, A. Gimpel, V. Stelzenmüller, N. Hillgruber, C. Grote, A. Mochtak, D. Czybulka, J. Assheuer, W. Koppe, H. Huthsfeldt, P. Breckling, B. H. Buck (Bremerhaven: Project for Offshore Aquaculture Potentials, Federal Ministry of Food, Agriculture and Consumer Protection No. GZ: 511-06.01-28-1-73.009-10).

Gutiérrez, A., Correa, T., Muñoz, V., Santibañez, A., Marcos, R., Cáceres, C., et al. (2006). Farming of the giant kelp Macrocystis pyrifera in southern Chile for development of novel food products. J. Appl. Phycol. 18, 259-267. doi: 10.1007/s10811-006-9025-y

Halling, C., Aroca, G., Cifuentes, M., Troell, M., and Buschmann, A. H. (2005). Comparison of suspended cultivation methods of Gracilaria chilensis in an integrated seaweed and fish cage culture. Aquacult. Int. 13, 409-422. doi: 10.1007/s10499-005-6977-x

Harrison, P. J., and Hurd, C. (2001). Nutrient physiology of seaweeds: application of concepts to aquaculture. Cahiers Biol. Mar. 42, 71-82.

He, W., Yttervik, R., Olsen, G. P., Ostvik, I., Jimenez, C., Impelluso, T., et al. (2015). A case study of multi-use platform: Aquaculture in offshore wind farms, Poster no 54, EWEA Offshore 2015 (Copenhagen).
Hernández-Miranda, E., Quiñones, R. A., Aedo, G., Valenzuela, A., Mermoud, N., Román, C., et al. (2010). A major fish stranding caused by a natural hypoxic event in a shallow bay of the eastern South Pacific Ocean. J. Fish Biol. 76, 1543-1564. doi: 10.1111/j.1095-8649.2010.02580.x

Hernández-Miranda, E., Veas, R., Anabalón, V., and Quiñones, R. A. (2017). Short-term alteration of biotic and abiotic components of the pelagic system in a shallow bay produced by a strong natural hypoxia event. PLoS ONE 12:e0179023. doi: 10.1371/journal.pone.0179023.

Hernández-Miranda, E., Veas, R., Labra, F. A., Salamanca, M., and Quiñones, R. A. (2012). Response of the epibenthic macrofaunal community to a strong upwelling-driven hypoxic event in a shallow bay of the southern Humboldt Current System. Mar. Environ. Res. 79, 16-28. doi: 10.1016/j.marenvres.2012.04.004

Hesley, C. (1997). "Open ocean aquaculture: chartering the future of ocean farming," in Proceedings of an International Conference, (Maui: University of Hawaii Sea Grant College Program), UNIHI-Seagrant-CP-98-08, p. 353.

Holthuijsen, L. H. (2007). Waves in Oceanic and Coastal Waters. New York, NY: Cambridge University Press.

Hortimare (2016). Propagating Seaweed for a Sustainable Future. Available online at: http://www.hortimare.com/ (Accessed October 22, 2016).

HR (2011). National Sustainable Offshore Aquaculture Act of 2011. 112th congress, 1 st Session in the house of representatives.

Hughes, A. D., and Black, K. D. (2016). Going beyond the search for solutions: understanding trade-offs in European integrated multi-trophic aquaculture development. Aquacult. Environ. Interact. 8, 191-199. doi: 10.3354/aei00174

Hundt, M., Goseberg, N., Wever, L., Ebeling, M., Schlurmann, T., Dubois, J., et al. (2011). "Multiple nutzung und co-management von offshore strukturen: marine aquakultur und offshore windparks," in Tagungsband, 8. FZKKolloquium. Maritimer Wasserbau und Küsteningenieurwesen (Bremerhaven: Forschungszentrum Küste (FZK), Gemeinsame Einrichtung der Leibniz Universität Hannover und der technischen Universität Braunschweig), $127-140$.

ICES (2012). Report of the Study Group on Social Dimensions of Aquaculture (SGSA). Stockholm.

Jansen, H. M., Van Den Burg, S., Bolman, B., Jak, R. G., Kamermans, P., Poelman, M., et al. (2016). The feasibility of offshore aquaculture and its potential for multi-use in the North Sea. Aquacult. Int. 24, 735-756. doi: 10.1007/s10499-016-9987-y

Kamermans, P., Schellenkes, T., and Beukers, R. (2011). Verkenning Van Mogelijkheden voor Mosselteelt op Noordzee. IMARES Rapport C021/11. Available online at: http://edepot.wur.nl/166223 (in Dutch)

Kapetsky, J. M., Aguilar-Manjarrez, J., and Jenness, J. (2013). "A global assessment of potential for offshore mariculture development from a spatial perspective," in FAO Fisheries and Aquaculture Technical Paper No. 549 (Rome, $\mathrm{FAO})$.

KEPCO and KIOST (2016). Co-location of Fisheries with Offshore Wind Farm: An Overview of Research Carried out in KEPCO Research Institute \& KIOST. Korea Electric Power Cooperation-Research Institute (KEPCO) and Korean Institute of Ocean Science and Technology (KIOST).

KFM (2014). Kames Fish Farming Ltd., Trial Offshore Seaweed Longlines, Kilmelford-Argyll (Accessed June 2, 2016).

Kite-Powell, H. (2017). "Economics of multi-use and co-location," in Aquaculture Perspective of Multi-Use Sites in the Open Ocean: The Untapped Potential for Marine Resources in the Anthropocene, eds B. H. Buck and R. Langan (Cham: Springer), 233-249.

Kona Blue Water Farms (2009). KBWF Supplemental, EA. Available online at: http://www.kona-blue.com/communityrelations.php (Accessed December 2009).

Korzen, L., Abelson, A., and Israel, A. (2016). Growth, protein and carbohydrate contents in Ulva rigida and Gracilaria bursa-pastoris integrated with an offshore fish farm. J. Appl. Phycol. 28, 1835. doi: 10.1007/s10811-0150691-5

Krause, G., and Mikkelsen, E. (2017). "The socio-economic dimensions of offshore aquaculture in a multi-use setting," in Aquaculture Perspective of Multi-Use Sites in the Open Ocean: The Untapped Potential for Marine Resources in the Anthropocene, eds B. H. Buck and R. Langan (Cham: Springer), 163-186. 
Krause, G., Brugere, C., Diedrich, A., Ebeling, M., Ferse, S., Mikkelsen, E., et al. (2015). A revolution without people? Closing the peoplepolicy gap in aquaculture development. Aquaculture 447, 44-55. doi: 10.1016/j.aquaculture.2015.02.009

Krause, G., Buck, B. H., and Rosenthal, H. (2003). "Multifunctional use and environmental regulations: potentials in the offshore aquaculture development in Germany," in Rights and Duties in the Coastal Zone, Multidisciplinary Scientific Conference on Sustainable Coastal Zone Management (Stockholm), 6.

Krause, G., Griffin, R. M., and Buck, B. H. (2011). "Perceived concerns and advocated organisational structures of ownership supporting 'offshore wind farm - mariculture integration,"' in From Turbine to Wind Farms: Technical Requirements and Spin Off Products, eds G. Krause (Rijeka: InTech; Open Access Publisher), 203-218.

Landsberg, J. H. (2002). The effects of harmful algal blooms on aquatic organisms. Rev. Fish. Sci. 10, 113-390. doi: 10.1080/20026491051695

Langan, R. (2001). "Advances in submerged longline culture of blue mussels Mytilis edulis in the open ocean," in Open Ocean Aquaculture, I V, Symposium Program and Book of Abstracts, eds C. J. Bridger, and T. H. Reid. (Ocean Springs, MS; St. Andrews, NB: Mississippi-Alabama Sea Grant Consortium), 73-74.

Langan, R. (2004). Balancing marine aquaculture inputs and extraction: combined culture of finfish and bivalve molluscs in the open ocean. Bull. Jpn Fish. Res. Agency Suppl. 1, 51-58.

Langan, R. (2007). "Results of environmental monitoring at an experimental offshore farm in the Gulf of Maine: Environmental conditions after seven years of multi-species farming," in Open Ocean Aquaculture- Moving Forward, eds C. S. Lee and P. J. O’Bryen (Hawaii: Oceanic Institute), 57-60.

Langan, R. (2012). "Mussel culture: innovations in deep water," in Sustainability Science in Aquaculture. Encyclopedia of Sustainability Science and Technology, eds B. A. Costa-Pierce and G. G. Page (New York, NY: Springer).

Langan, R., and Horton, F. (2003). Design, operation and economics of submerged longline mussel culture in the open ocean. Bull. Aquac. Assoc. Can. 103, 11-20.

Langlois, J., Sassi, J.-F., Jard, G., Steyer, J.-P., Delgenes, J.-P., and Hélias, A. (2012). Life cycle assessment of biomethane from offshore cultivated seaweed. Biofuels Bioprod. Bioref. 6, 387-404. doi: 10.1002/bbb.1330

Lasserre, T., and Delgenès, J. P. (2012). WindSeaFuel: Production de Macro-Algues Pour une Valorisation en Méthane et Autres Bioproduits. ANR Bioénergies 2009 Poster, ANR-09-BIOE-05, Label pôle, DERBI-TRIMATEC.

Lin, D. T., and Bailey-Brock, J. (2008). Partial recovery of infaunal communities during a fallow period at an open-ocean aquaculture. Mar. Ecol. Prog. Ser. 371, 65-72. doi: 10.3354/meps07675

Lindahl, O. (2011). "Mussel farming as a tool for re-eutrophication of coastal waters: experiences from Sweden," in Shellfish Aquaculture and the Environment, ed S. Shumway (Wiley-Blackwell), 217-235.

Lindahl, O., Hart, R., Hernroth, B., Kollberg, S., Loo, L. O., Olrog, L. et al. (2005). Improving marine water quality by mussel farming: A profitable solution for Swedish society. Ambio 34, 131-138. doi: 10.1579/0044-7447-34. 2.131

Løland, G. (1993). Current forces on, and water flow through and around, floating fish farms. Aquacult. Int. 1, 72-89. doi: 10.1007/BF006 92665

Lovatelli, A., Aguilar-Manjarrez, J., and Soto, D. (2013). "Expanding mariculture farther offshore: technical, environmental, spatial and governance challenges," in FAO Technical Workshop (Orbetello; Rome: FAO Fisheries and Aquaculture Proceedings) Includes a CD-ROM containing the full document (314 pp.).

Lüning, K., and Buchholz, C. (1996). Massenkultur Mariner Makroalgen bei Helgoland zur Gewinnung von Phycokolloiden und zur Verwendung als Biosorptionsmittel. BAH Report Helgoland. Biologische Anstalt Helgoland (BAH).

Marfaing, H. (2014). "WinSeaFuel project: biomethane and other bio product developments from offshore seaweed culture," in 21st International Seaweed Symposium of the International Seaweed Association, (Bali).
Marra, J. (2005). When will we tame the oceans? Nature 436, 175-176. doi: $10.1038 / 436175 \mathrm{a}$

McElwee, J. (1996). "Offshore salmon farming: the good, the bad and the ugly," in Open Ocean Aquaculture: Proceedings of an International Conference, ed M. Polk (Portland, :New Hampshire/Maine Sea Grant College Program), UNHMP-CP SG-96-9, 193-201.

McVey, J. P., and Buck, B. H. (2008). "IMTA-design within an offshore wind farm, "aquaculture for human wellbeing-the asian perspective"," in The Annual Meeting of the World Aquaculture Society (Busan).

Michler-Cieluch, T. (2008). Co-Management Processes in Integrated Coastal Management - The Case of Integrating Marine Aquaculture in Offshore Wind Farms. Ph.D., Hannover: University Hamburg.

Michler-Cieluch, T., and Krause, G. (2008). Perceived concerns and possible management strategies for governing wind farm-mariculture integration. Mar. Policy 32, 1013-1022. doi: 10.1016/j.marpol.2008.02.008

Michler-Cieluch, T., Krause, G., and Buck, B. H. (2009a). Reflections on integrating operation and maintenance activities of offshore wind farms and mariculture. Ocean Coast. Manage. 52, 57-68. doi: 10.1016/j.ocecoaman.2008. 09.008

Michler-Cieluch, T., Krause, G., and Buck, B. H. (2009b). Marine aquaculture within offshore wind farms: social aspects of multiple use planning. GAIA 18, 158-162.

Millennium Ecosystem Assessment (2005). Ecosystems and Human Well-being: Wetlands and Water Synthesis. Washington, DC: World Resources Institute.

Molloy, S. D., Pietrak, M. R., Bouchard, D. A., and Bricknell, I. (2011). Ingestion of Lepeophtheirus salmonis by the blue mussel Mytilus edulis. Aquaculture 311, 61-64. doi: 10.1016/j.aquaculture.2010.11.038

Myrseth, B. (2017). Closed-Containment Aquaculture in Norway. New Approaches to Unlock the Potential of Offshore Aquaculture. Berlin: Internationale Innovationswerkstatt Aquakultur - Vertretung des Landes Schleswig-Holstein beim Bund.

Navarrete-Mier, F., Sanz-Lázaro, S., and , Marin, A. (2010). Does bivalve mollusc polyculture reduce marine fin fish farming environmental impact? Aquaculture 306, 101-107. doi: 10.1016/j.aquaculture.2010.06.013

Naylor, L., Goldburg, R. J., Primavera, J., Kautsky, K., Beveridge, M., Clay, J., et al. (2000). Effect of aquaculture on world fish supplies. Nature 405, 1017-1024. doi: $10.1038 / 35016500$

Naylor, R., and Burke, M. (2005). Aquaculture and ocean resources: raising tigers of the sea. Annu. Rev. Environ. Resour. 30, 185-218. doi: 10.1146/annurev.energy.30.081804.121034

Neori, A., Chopin, T., Troell, M., Buschmann, A., Kraemer, G. P., Halling, C., et al. (2004). Integrated aquaculture: rationale, evolution and state of the art emphasizing seaweed biofiltration in modern mariculture. Aquaculture 231, 361-391. doi: 10.1016/j.aquaculture.2003.11.015

Neushul, M., and Harger, B. W. W. (1985). Studies of biomass yield from a near-shore macroalgal test farm. J. Solar Energy Eng. 107, 93-96. doi: $10.1115 / 1.3267661$

Neushul, M., Benson, J., Harger, B. W. W., and Charters, A. C. (1992). Macroalgal farming in the sea: water motion and nitrate uptake. J. Appl. Phycol. 4, 255-265. doi: $10.1007 / \mathrm{BF} 02161211$

NOAA (2008). Offshore Aquaculture in the United States: Economic Considerations, Implications \& Opportunities. Available online at: www.aquaculture.noaa.gov/ pdf/econ/Econ_rpt_all.pdf

Nobre, A. M., Robertson-Andersson, D., Neori, A., and Sankar, K. (2010). Ecological-economic assessment of aquaculture options: comparison between abalone monoculture and integrated multi- trophic aquaculture of abalone and seaweeds. Aquaculture 306, 116-126. doi: 10.1016/j.aquaculture.2010. 06.002

North, W. J. (1987). "Oceanic farming of Macrocystis. The problems and non-problems," in Seaweed Cultivation for Renewable Resources, eds K. T. Bird and P. H. Benson (Amsterdam, NY: Developments in Aquaculture and Fisheries Sciences), 39-67.

OECD (2013). Interconnected Economies: Benefiting from Global Value Chains OCES Synthesis Report.

Olsen, Y., Slagstad, D., and Vadstein, O. (2005). Assimilative carrying capacity: contribution and impact on the pelagic system. Eur. Aquacult. Soc. 35, 50-52. 
Oohusa, T. (1993). "The cultivation of Porphyra "Nori", in Seaweed Cultivation and Marine Ranching, eds A. T. Critchley and M. Ohno (Yokosuka: Japan International Cooperation Agency), 57-73.

Oyinlola, M. A., Reygondeau, G., Wabnitz, C. C. C., Troell, M., and Cheung, W. W. L. (2018). Global estimation of areas with suitable environmental conditions for mariculture species. PLoS ONE 13:e0191086. doi: 10.1371/journal.pone.0191086

Ozgul, A., and Angel, D. L. (2013). Aggregations of wild fish at net-cage fish farms in the Gulf of Aqaba-Red Sea; implications for fisheries management and conservation. Aquacult. Environ. Interact. 4:135-145. doi: 10.3354/aei00076

Partridge, G. J., Sarre, G. A., Ginbey, B. M., Kay, G. D., and Jenkins, G. I. (2006). Finfish production in a static, inland saline water body using a Semi-Intensive Floating Tank System (SIFTS). Aquacult. Eng. 35, 109-121. doi: 10.1016/j.aquaeng.2005.09.001

Pérez, J. E., Alfonsi, C., Nirchio, M., Munoz, C., and Gomez, J. A. (2003). The introduction of exotic species in aqua- culture: A solution or part of the problem? Interciencia 28, 234-238.

Peteiro, C., and Freire, Ó. (2012). Observations on fish grazing of the cultured kelps Undaria pinnatifida and Saccharina latissima (Phaeophyceae, Laminariales) in Spanish Atlantic waters. AACL Bioflux 5, 189-196.

Pogoda, B. (2012). Farming the High Seas: Biological Performance of the Offshore Cultivated Oysters Ostrea edulis and Crassostrea gigas in the North Sea. Ph.D. thesis, Bremen: University of Bremen, 188.

Pogoda, B., Buck, B. H., and Hagen, W. (2011). Growth performance and condition of oysters (Crassostrea gigas and Ostrea edulis) farmed in an offshore environment (North Sea, Germany). Aquaculture 319, 484-492. doi: 10.1016/j.aquaculture.2011.07.017

Pogoda, B., Jungblut, S., Buck, B. H., and Hagen, W. (2012). Parasitic infestations of copepods in oysters and mussels: differences between nearshore wild banks and an offshore cultivation site in the German Bight. J. Appl. Ichthyol. 28, 756-765. doi: 10.1111 /jai.12025

Pogoda, P., Buck, B. H., Saborowski, R., and Hagen, W. (2013). Biochemical and elemental composition of the offshore cultivated oysters Ostrea edulis and Crassostrea gigas, Aquaculture 400, 53-60. doi: 10.1016/j.aquaculture.2013.02.031

Polk, M. (1996). "Open ocean aquaculture," in Proceedings of an International Conference (Portland: New Hampshire/Maine Sea Grant College Program Rpt No) UNHMP-CP-SG-96-9, 640.

Posadas, B. C., and Bridger, C. J. (2003). "Economic feasibility of offshore aquaculture in the Gulf of Mexico," in Open Ocean Aquaculture: From Research to Commercial Reality, eds C. J. Bridger and B. A. Costa-Pierce (Baton Rouge, LA: World Aquaculture Society), 307-318.

Reid, G. K., Chopin, T., Robinson, S. M. C., Azevedo, P., Quinton, M., and Belyea, E. (2013). Weight ratios of the kelps, Alaria esculenta and Saccharina latissima, required to sequester dissolved inorganic nutrients and supply oxygen for Atlantic salmon, Salmo salar, in Integrated Multi-Trophic Aquaculture systems. Aquaculture 408-409, 34-46.

Reid, G. K., Liutkus, M., Robinson, S. M. C., Chopin, T., Blair, T., Lander, T., et al. (2009). A review of the biophysical properties of salmonid faeces: implications for aquaculture waste dispersal models and integrated multi-trophic aquaculture. Aquacult. Res. 40, 257-273. doi: $10.1111 /$ j.1365-2109.2008.02065.x

Rosenberg, R., and Loo, L. O. (1983). Energy-flow in a Mytilus edulis culture in western Sweden. Aquaculture 35, 151-161. doi: 10.1016/0044-8486(83)90 082-0

Rosenthal, H., Costa-Pierce, B. A., Krause, G., and Buck, B. H. (2012a). "Bremerhaven declaration on the future of global open ocean aquaculture, Part I: preamble and recommendations," in Aquaculture Forum on Open Ocean Aquaculture Development - From Visions to Reality: The future of offshore farming. Funded by: Investment in sustainable fisheries co-financed by the European Union (European Fisheries Fund - EFF), Ministry of Economics, Labour and Ports (Free Hanseatic City of Bremen), The Bremerhaven Economic Development Company Ltd.

Rosenthal, H., Costa-Pierce, B. A., Krause, G., and Buck, B. H. (2012b). "Bremerhaven Declaration on the Future of Global Open Ocean Aquaculture, Part II: Recommendations on subject areas and justifications," in Aquaculture Forum on Open Ocean Aquaculture Development - From visions to reality: The future of offshore farming. Funded by: Investment in sustainable fisheries cofinanced by the European Union (European Fisheries Fund - EFF), Ministry of Economics, Labour and Ports (Free Hanseatic City of Bremen), The Bremerhaven Economic Development Company Ltd.

Ryan, J. (2004). Farming the Deep Blue. Dublin: Sea Fisheries Board and Marine Institute.

SAPEA (2017). Food from the Oceans. SAPEA - Science Advice for Policy by European Academies, Evidence Review Report No.1, Brussels.

Scarratt, D. J. (1993). A Handbook of Northern Mussel Culture. Montague, PE: Island Press

SES (2015a). Patented Seaweed Carrier System by SES, Patent No. EP 09836439.1. SES - Seaweed Energy Solutions (Trondheim).

SES (2015b). Seaweed Carrier System for the Cultivation of Macroalgae in Offshore Environments Patented by SES-Seaweed Energy Solutions (Trondheim).

Simpson, H. (2015). Uncertainty for Marlborough Sounds Mussel Farmers. The Marlborough Express.

Skår, C. K., and Mortensen, S. (2007). Fate of infectious salmon anaemia virus (ISAV) in experimentally challenged blue mussels Mytilus edulis. Dis. Aquat. Organ. 74, 1-6. doi: 10.3354/dao074001

Stelzenmüller, V., Gimpel, A., Gopnik, M., and Gee, K. (2017). "Aquaculture siteselection and marine spatial planning: the roles of GIS-based tools and models," in Aquaculture Perspective of Multi-Use Sites in the Open Ocean: The Untapped Potential for Marine Resources in the Anthropocene, eds B. H. Buck and R. Langan (Cham: Springer), 131-148.

Stevens, C., Plew, D., Hartstein, N., and Fredriksson, D. (2008). The physics of open water shellfish aquaculture. Aquacult. Eng. 38, 145-160. doi: 10.1016/j.aquaeng.2008.01.006

Stickney, R. R. (1999). “Joining forces with industry," in Proceedings of the Third International Conference on Open Ocean Aquaculture (Corpus Christi, TX).

Swift, M.R., (2016). Construction of a Double-Net IMTA Raft for Steelhead Trout and Blue Mussel Aquaculture. N.H. Sea Grant Development Project Completion Report.

TEEB (2010). Rethinking Global Biodiversity Strategies: Exploring Structural Changes in Production and Consumption to Reduce Biodiversity Loss. The Economics of Ecosystems and Biodiversity Project (TEEB), Netherlands Environmental Assessment Agency, The Hague/Bilthoven.

Troell, M., and Norberg, J. (1998). Modelling output and retention of suspended solids in an integrated salmon-mussel culture. Ecol. Model. 110, 65-77. doi: 10.1016/S0304-3800(98)00042-8

Troell, M., Chopin, T., Reid, G., Robinson, S., and Sara, G. (2011). Letter to the editor of aquaculture. Aquaculture 313, 171-172. doi: 10.1016/j.aquaculture.2011.01.012

Troell, M., Halling, C., Neori, A., Buschmann, A. H., Chopin, T., Yarish, C., et al. (2003). Integrated mariculture: asking the right questions. Aquaculture 226, 69-90. doi: 10.1016/S0044-8486(03)00 469-1

Troell, M., Halling, C., Nilsson, A., Buschmann, A. H., Kautsky, N., and Kautsky, L. (1997). Integrated marine cultivation of Gracilaria chilensis (Gracilariales, Rhodophyta) and salmon cages for reduced environmental impact and increased economic output. Aquaculture 156, 45-61. doi: 10.1016/S0044-8486(97)00080-X

Troell, M., Jonell, M., and Henriksson, P. J. G. (2017). Ocean space for seafood. Nat. Ecol. Evol. 1, 1224-1225. doi: 10.1038/s41559-0170304-6

Troell, M., Joyce, A., Chopin, T., Neori, A., Buschmann, A. H., and Fang, J. G. (2009). Ecological engineering in aquaculture - potential for integrated multitrophic aquaculture (IMTA) in marine offshore systems. Aquaculture 297, 1-9. doi: 10.1016/j.aquaculture.2009.09.010

Troell, M., Kautsky, N., and Folke, C. (1999). Applicability of integrated coastal aquaculture systems. Ocean Coast. Manage. 42, 63-69.

Troell, M., Robertson-Andersson, D., Anderson, R. J., Bolton, J. J., Maneveldt, G., Halling, C., et al. (2006). Abalone farming in South Africa: an overview with perspectives on kelp resources, abalone feed, potential for on-farm seaweed production and socio-economic importance. Aquaculture 257, 266-281. doi: 10.1016/j.aquaculture.2006.02.066

Turner, R. (2001). "Offshore mariculture: site evaluation," in Options Méditerranéennes - Mediterranean Offshore Mariculture. Etudes et Recherches, 
eds J. Muir and B. Basurco (Zaragoza: CIHEAM, INO Reproducciones), 141-157.

Upton, H., and Buck, E. H. (2010). Open Ocean Aquaculture. CRS Report for Congress, Congressional Research Service.

Venayagamoorthy, S. K., Ku, H., Fringer, O. B., Chiu, A., Naylor, R. L., and Koseff, J. R. (2011). Numerical modelling of aquaculture dissolved waste transport in a coastal embayment. Environ. Fluid Mech. 11, 329-352. doi: 10.1007/s10652-011-9209-0

Weiß, M., and Buck, B. H. (2017). Blue Mussel (Mytilus edulis) meat as a partial fish meal replacement for the diet in turbot aquaculture. J. Appl. Ichthyol. 33, 354-360.

Westermeier, R., Gomez, I., and Rivera, P. (1993). Suspended farming of Gracilaria chilensis (Rhodophyta, Gigartinales) at Cariquilida River, Maullin, Chile. Aquaculture 113, 215-229. doi: 10.1016/0044-8486(93)90475-E

Wildish, D. J., and Kristmanson, D. D. (1988). Growth response of giant scallops to periodicity of flow. Mar. Ecol. Prog. Ser. 42, 163-169. doi: 10.3354/meps042163

Zamora, L. N., Yuan, X., Carton, A. G., and Slater, M. (2016). Role of deposit-feeding sea cucumbers in integrated multitrophic aquaculture: progress, problems, potential and future challenges. Rev. Aquacult. 10, 57-74. doi: $10.1111 /$ raq. 12147
Zeiber, R. (2015). UNH-led Team Designs Aquaculture Raft to Provide Four-Season Source of Seafood and Sea Veggies. Integrated Multi-Trophic Aquaculture in New England. New Hampshire Sea Grant Communication and Information. Available online at: http://seagrant.noaa.gov (Accessed March 9, 2018).

Conflict of Interest Statement: BB and GK were employed by the company Seakult Buck, Krause GbR.

The other authors declare that the research was conducted in the absence of any commercial or financial relationships that could be construed as a potential conflict of interest.

Copyright (C) 2018 Buck, Troell, Krause, Angel, Grote and Chopin. This is an openaccess article distributed under the terms of the Creative Commons Attribution License (CC BY). The use, distribution or reproduction in other forums is permitted, provided the original author(s) and the copyright owner are credited and that the original publication in this journal is cited, in accordance with accepted academic practice. No use, distribution or reproduction is permitted which does not comply with these terms. 